Danilo Trbojević

\author{
Doktorand na Odeljenju za etnologiju i antropologiju, \\ Filozofski fakultet, Univerzitet Beogradu \\ danilotrbojevic@yahoo.com
}

\title{
Između muzike i nasilja: ,šutka" kao ritualizovani performans identiteta i ideologija ${ }^{1}$
}

Apstrakt: Alternativna muzička scena u Beogradu nastaje i razvija se gotovo paralelno sa zapadnom. Pripadnici muzičkih potkultura su, do određene mere, usvajali norme, vrednosti i obrasce ponašanja po uzoru na (zapadni) model. Ipak, domaća ,,andergraund" scena predstavlja odraz konstantnog procesa glokalizacije pre nego potpunog saobraženja globalnog i lokalnog. Iako su „scene” u početku bile donekle razdvojene, promene socijalnog, kulturnog i političkog konteksta dovodile su do povremenog prožimanja različitih supkulturnih grupa. Pomenuta prožimanja odrazila su se i na koncept ultimativnog spektakla, performansa supkulturne socijalizacije i komunikacije - koncerta. Specifičan aspekt individualnog i kolektivnog učešća u performansu savremenih rok koncerata, kojim se ovaj tekst bavi, jeste ,šutka”. Istraživanje ima za cilj da ukaže na višeslojnost i kompleksnost paralelnih performansa koji se odvijaju na bini, u publici i međuprostoru, na način specifičan za metal i pank ,,andergraund koncerte”. U članku nastojim da istražim na kom nivou i do koje mere su navedene potkulture zaista kontrakulture, tj. na koje načine na koncertima, kroz ,šutku”, one preispituju obrasce, vrednosti, odnose moći, hijerarhije pa i hegemonije šireg društva, a do koje mere su refleksije dominantne kulture u malom.

Ključne reči: ,šutka”, koncert, potkultura, andergraund, nasilje, identitet, performans

${ }^{1}$ Ovaj članak je nastao kao test istraživanje sa ciljem da dâ uvid u kompleksnost fenomena kao i pluralizam diskursa o temi muzike, nasilja, supkulture, stila, performansa, socijalizacije i andergraund kulture. Sa temom i problematikom izloženom u ovom članku imao sam 2015. godine izlaganje prvo na Summer school, Faculty of arts and Humanities of the University of Porto, da bih nekoliko dana kasnije izlagao i na međunarodnoj konferenciji „KISMIF” (Porto 2015) 2018.godine. U nešto drugačijem obliku ovo istraživanje je predstavljeno i na nacionalnoj konferenciji „Antropologija muzike” održanoj marta 2018. godine u organizaciji Instituta i Odeljenja za etnologiju i atropologiju Filozofskog fakulteta, Univerziteta u Beogradu. 
Klinci danas imaju $i$ više razloga da budu besni ili uznemireni, društvo ih praktično gura u tom pravcu, u suštini su zarobljeni, saterani u ćošak, i moraju da se bore kako bi se izvukli iz ćoškova...

- Da li je svet postao ružniji u poslednjih nekoliko godina? Hm, sigurno nije postao lepši... ... a onda opet, pank rok nikad i nije bio lep ${ }^{2}$

Keith Morris (Black flag, Circle jerks)

The Decline of Western Civilization III [1998]

\section{Uvod}

U ovom radu polazim od više puta potvrđenog utiska da sagovornici koji nisu imali neposrednih iskustava, niti prethodnih znanja o pojavi o kojoj je reč nju doživljavaju kao nasilni haos, nešto poput antiteze kulturi i civilizovanom ponašanju, dok su članovi potkultura koji je izvode prepoznati kao „drugost”. Ta činjenica me je podsetila na masovnu histeriju koja se periodično javljala na Zapadu, posebno u Americi osamdesetih i devedesetih godina 20. veka. Pomenute histerije su često pokretane tako što je u medijima metal ili pank pokret bio označen kao opasan, zao ili destruktivan, što je pripisivano i pripadnicima pomenutih scena. Loš uticaj ovih pokreta nije bio sveden samo na njihove pripadnike, već i na odnos potkulture i društva (Clinton 1993, Merriam 1964). Okidač za te talase masovne histerije često su bila krivična dela, ubistva ili samoubistva koje su medijske ili političke figure u medijima dovodile u direktnu vezu sa žanrom, scenom ili čak samim bendovima. Veštački uspostavljena veza između TV priloga o krivičnim delima i potkulturama bila je pretpostavljena konstanta nasilja, opasnosti i „drugosti” koje mediji, institucije i šire društvo dovode u vezu s alternativnom, a posebno ,andergraund” scenom. „Drugost” bi bio ključni termin u definisanju, često oprečnog, odnosa potkultura i šireg društva. Metal i pank muzika su bili označeni ne samo kao društveni problem, već antiteza (zapadne) civilizacije. ${ }^{3}$ Primer za prethodnu tvrdnju je sučeljavanje u televizijskom tok-šou Opre Vinfri (Oprah Winfrey) 1985. godine. Tom prilikom su pank, hip-hop i metal muzičari poput Džela Biafre (Jello Biafra) iz Ded Kenedisa (Dead Kennedys) ili Ajs-Tija (Ice-T, Body count) vodili debatu sa Meri „Tiper” Gor (Merry Tipper Gore), drugom damom Amerike, o tome da li su

2 The Decline of Western Civilization III [1998], 7:09

${ }^{3} \mathrm{Za}$ veliki broj muzičkih grupa i pripadnika supkultura panka ili metala, antagonizam prema mejnstrim kulturi, širem društvu ili ideologiji i jeste (manifestni) razlog pa čak i cilj postojanja potkulture. Jedan od najpoznatijih serijala dokumentarnih filmova sa početka 80ih godina 20. veka, The Decline Of Western Civilization (1981) govori upravo o uticaju društvene represije i nemaštine na formiranje potkulturnih scena. 
eksplicitne teme i vizuelni identitet zastupljen na muzičkim izdanjima posledica ili deo uzroka društvenih problema. ${ }^{4}$ Potkulturi tog vremena je nametnuta uloga „žrtvenog jarca" (Girard 1989), gde su ovi pokreti prepoznati kao deo uzroka a ne posledice društvenog ili kulturnog propadanja. Pomenuti antagonizam kulminirao je suđenjima početkom devedesetih godina dvadesetog veka, na kojima su se pojavljivali frontmeni grupa poput Džudas prist ${ }^{5}$ (Judas priest), Tvisted sister (Twisted sister) pa i sam Ozi Ozborn (Ozzy Osbourne, vokal grupe Black sabbath) koji su branili kako svoju muziku i tekstove, tako i pokret, ${ }^{6}$ u čemu su i uspeli u smislu da su optužbe odbačene. Ipak, stigma je ostala, stereotipi su ostali, strah je ostao, muzika je ostala, ali je i ,šutka" ostala. Danas je situacija nešto drugačija. Odavno je prošlo vreme kada su pank ili metal bili popularni žanrovi, tiraži ploča su se višestruko smanjili kao i brojnost publike, a scene su se praktično vratile na marginu, na ono što ispitanici gotovo sa ponosom označavaju kao ,andergraund”, mali, intimni, specifični prostor socijalne interakcije.

Kroz dekonstrukciju paralelnih performansa, odnosno, analizu različitih aspekata „šutke" i načina i motiva učestvovanja, od kolektivnog ka individualnom, nastojim da pomognem razumevanje ovog spektakla i preispitam vezu ,šutke" i nasilja.?

\section{Teorijsko - metodološki okvir}

Pre nego što postavim teorijsko-metodološki okvir, bitno je naglasiti da je ovom istraživanju prethodilo ono koje je obrađivalo istu temu koristeći se drugačijim pristupom. Naime, u prethodnom istraživanju nastojao sam da razumem način na koji učesnici i posmatrači vide ,šutku” i svoje mesto u njoj. Pomenutu sam analizu bazirao na odgovorima dobijenih kroz intervju, odnosno, na narativima ispitanika. Najčešći iskaz o učešću u ,šutki” je bio da je ona „neka vrsta ventila za izbacivanje negativne energije” ili ,ples/igra u kojoj se razmenjuje pozitivna energija između samih učesnika, i učesnika i benda", što bi bila etnoeksplikacija. Problem ovakvog istraživačkog pristupa je bio taj što su

${ }^{4} \mathrm{https} / / /$ dangerousminds.net/comments/parental_advisory_explicit_content_jello_ biafra_vs_tipper_gore_on_oprah_199 Preuzeto 19. 72014.

5 https://www.nytimes.com/1990/07/17/arts/2-families-sue-heavy-metal-band-ashaving-driven-sons-to-suicide.html Preuzeto 19. 7. 2014.

${ }^{6} \mathrm{http}: / /$ www.vh1.com/news/54726/remembering-the-80s-heavy-metal-satanicpanic/ Preuzeto 19. 6. 2014.

7 Na ovoj stranici sam pronašao podatak o broju poginulih i povređenih u šutkama. Dok se broj poginulih broji u desetinama, broj povređenih je veći od stotine hiljada. http://www.nytimes.com/1996/05/09/nyregion/hard-core-threat-to-health-moshing-atrock-concerts.html Preuzeto 19. 6. 2014. 
se odgovori ponavljali i nisu davali previše informacija o višeslojnosti rituala, unutrašnjim tenzijama, kao ni o raznorodnim motivima učešća. U ovom radu odlučio sam da fenomen sagledam tako što ću idealističke stavove učesnika i kritičke iskaze ljudi, kojima ovaj fenomen nije poznat ili jasan, preispitati kroz analizu prostorno-fizičkog, neverbalnog ponašanja učesnika, ,šutke”. Preciznije, u analizi suprotstavljam ,šutku” kao idejni koncept, odnosno idealni model, koji usvajaju pripadnici potkultura, i njegovu fizičku inkarnaciju, tj. praksu izvođenja rituala. Kroz ovakav pristup sagledaću kada i na koji način se ostvaruje saradnja i jedinstvo, kada se ispoljavaju tenzije i koji faktori dovode do konflikta. Ideja ovog pristupa je da se dekonstruiše ritual, ukaže na njegovu kompleksnost, polifunkcionalnost i različite motive, kao i fizičke i simoličke načine učestvovanja različitih društvenih i potkulturnih grupa. Na ovaj način nastojim da razumem višeslojnost ,šutke" kao performansa i rituala u kome se preispituju ili potvrđuju različiti identiteti, ali i razrešuju socijalne drame i konflikti. Pored pomenutog, analiza nastoji da doprinese boljem razumevanju odnosa potkulture i kulture, odnosno, potkulture i društva.

Teorijska osnova na kojoj počiva analiza ,šutke” u ovom radu zasnovana je na ideji o ritualnoj prirodi fenomena unutar specifičnog fizičkog, socijalnog i simboličkog prostora ,andergraund" koncerta kao spektakla paralelnih performansa. Jelena Đorđević ističe da su karakteristike spektakla uticaj hipertrofiranih simbola na čula, način predstavljanja boljeg sveta kroz sistem ,,jednoznačnih simbola, znakova i alegorija", oblik eskapizma u odnosu na dominantnu realnost i performans koji jasno deli učesnike na izvođače i gledaoce (Đorđević 1997, 197). U ovom radu, kroz analizu iskaza ispitanika i prakse, nastojim da dođem do zaključka o tome koliko potkulturni okvir uspostavlja jedinstvo pripadnika, da li se i koliko razlikuje od obrazaca ponašanja i vrednosti šireg društva ili samo stvara iluziju zajedničkih motiva i ideala. Kao što će se u članku videti, scena, koncert i potkultura manifestacije su onoga što Viktor Tarner naziva komunitas, a što svakako svoj oblik i način delovanja, ali i uzrok ima u širem društvenom, istorijskom i političkom kontekstu (Turner 1969). Termin komunitas ovde koristim kako bi označio grupu ljudi koja se nalazi u liminalnom stanju u odnosu na šire društvo, koju karakterišu određena specifična pravila socijalizacije ili promišljanja stvarnosti. Iako često opozitna „mejnstrimu”, načela na kojima su organizacija i delovanje ovih grupa zasnovani u nesumnjivoj su vezi sa načinom života (pravilima) šireg društva. Razlike u predstavama o stvarnosti ili ideologijama ogledaju se kroz etička načela i politička uverenja (npr. antiseksizam, antifašizam), način oblačenja, komunikaciju i socijalializaciju pripadnika potkultura. Vilijam Cicos ističe upravo ideološku osnovu potkulturnih mikro scena poput anarho pank, Oi i strejt edža čiji članovi performiraju svoje ideologije u dva pravca, u odnosu jedni na druge i u odnosu na društvo. Ovi 
mikrogrupni performansi ideologija, po Cicosu, otelotvoreni su kroz načine ponašanja unutar specifičnog prostora koncerta. Autor povezuje ideološka načela, odnos prema dominaciji i pravilima, karakterističnim za određene grupe, s time kako pripadnici tih grupa verbalno i neverbalno performiraju svoju pripadnost (Tsitsos 1999). Miroslava Lukić Krstanović ističe kako su spektakli „,inspirativna i provokativna sredstva u teatralizaciji gradskog prostora, scena i arena", koje odražavaju različite i nove načine reprezentacije (urbanih) identiteta, umetničkih senzibiliteta i, za ovaj rad ključno, ideoloških formacija (Lukić Krstanović 2010, 20). Koncert posmatram kao spektakl u malom, prostor ritualnog performansa tj. arenu ideoloških sukoba, a samu „šutku” kao simbolički „boj”. U tom smislu, smatram da se u ,šutki” i na koncertu, kao paralelnim i prožimajućim performansima, kroz neverbalnu komunikaciju, pozicioniranje i telesne tehnike manifestuju i sukobljavaju različiti identiteti, ideologije i ideje. Ovakvi koncepti spektakla primenljivi su na primer ,andergraund” koncerta kao fizičkog i simboličkog prostora u kom se odigravaju paralelni performansi. Zašto paralelni? Smatram da u nekim slučajevima koncert i ,šutka" mogu biti koncipirani kao paralelni, preklapajući spektakli ${ }^{8}$, te da se kroz različite načine učestvovanja u „šutki” iskazuju kolektivni, mikrogrupni i individualni identiteti. Ova teza pronalazi potvrdu u rezultatima istraživanja već pomenutog Vilijema Cicosa (Tsitsos 1999), zatim Krega T. Palmera (Palmer 2005), Gabriele Ričis (Riches 2014) i drugih autora. Navedena ideja, po kojoj različite grupe, klase, rase ili rodovi na različite načine učestvuju u kulturi, a time i ritualima i iskazuju različite identitete, karakteristična je za neomarksističke autore i autore koji pripadaju talasu Studija kulture (Đorđević 2012, 26). Ako se vratim na teoriju performansa, po kojoj svako od nas performira unutar društva, kroz sistem signala koje šaljemo sebi i drugima kako bi naznačili ili ojačali svoju poziciju u društvenoj grupi, jasno je da kroz njih mi odražavamo i određene diskurse ali i društvene konflikte. Viktor Tarner, koji se bavio konfliktima u društvenoj strukturi Ndembu naroda, uvodi termin ,socijalna drama" kao oruđe za razumevanje tenzija i konflikta, te mehanizama koji kroz ritualnu formu služi razrešenju tenzije i socijalnoj kohe-

${ }^{8}$ Iako možemo reći da je ,šutka" samo deo koncerta kao spektakla, smatram da ona može biti spektakl ili performans unutar performansa. Pokušaću da ovo pojasnim kroz analogiju s drugom potkulturom - fudbalskim navijačima. Naime, ako posmatramo fudbalski meč, jasno je da je za većinu posmatrača to glavni i jedini spektakl kog su deo i navijači na tribinama. Čini se, ipak, da za potkulturu fudbalskih navijača samo prisustvo, način navijanja i koreografije po sebi, a posebno u opoziciji sa navijanjem suparničkih navijača, često predstavlja važniji događaj pa i spektakl od same fudbalske utakmice. Naravno, na osnovu novinskih izveštaja i članaka jasno je da utakmica, odnosno tribina, navijačima takođe služi kao plato za iskazivanje raznorodnih identiteta, kao i ispoljavanja unutrašnjih, međugrupnih i socijalno-političkih/ideoloških tenzija. 
ziji (Turner 1974). Za Tarnera se definicija rituala odnosi na ritualne performanse koji uključuju manipulaciju simbolima (koji mogu biti predmeti, reči, gestovi itd), a koji se odnose na religijska verovanja. Za pomenutog autora ritual je deo procesa socijalne drame koji za cilj ima uspostavljanje konfliktnog ekvilibrijuma društva. Ritual uključuje manipulaciju simbolima koji su nosioci značenja, a koji čine i najmanji deo ritualne aktivnosti. Simboli su višeznačni, pomažu grupnu koheziju i zadovoljavaju emotivne potrebe pojedinaca. Rituali, dakle, mogu imati različite funkcije i ciljeve za različite kategorije učesnika, a svakako predstavljaju oblik pregovaranja marginalizovane grupe i šireg društva, ali su deo i unutargrupnog pregovaranja. Smatram da koncert kao performans (spektakl), i ritual ,šutke" ne odražavaju homogenost ideja, na kojima potkulturna grupa počiva, već stvara iluziju jedinstva i zajedničkih ciljeva. U tom smislu smatram da treba krenuti od analize kolektivnog učestvovanja, zatim analizirati mikro grupni pristup ritualu, da bi se na kraju dotakli marginalnih grupa i individualnih motiva učešća.

Uzimajući prethodno rečeno u obzir, jasno je da analiza višeslojnog rituala poput ,šutke" svakako zahteva raznovrsne teorijske pristupe. U tom smislu, analizu počinjem iz najšireg ugla posmatranja ,šutke" kao kolektivnog rituala kojem je jedna od funkcija socijalizacija i grupna kohezija, dok potkulturu posmatram kao plato za izgradnju identiteta i sticanja socijalnog i simboličkog kapitala (Bourdieu 1984). Za ovaj deo rada koristan je pristup Krega Palmera koji u ovome i vidi osnovnu funkciju ,šutke” koristeći se teorijom uzajamnog altruizma, kao idejom o učenju kroz rituale koji preispituju društvene norme i konstruišu veze između učesnika, jačajući socijalnu koheziju. Na drugom nivou „šutku” posmatram kao simboličku arenu u kojoj se performiraju ideologije, preispituju odnosi moći i izražavaju unutar grupne i šire društvene tenzije. Kroz princip čistog i opasnog (Daglas 2001), odnosno poželjnog i nepoženog saznajem nešto više o dinamici i strukturi, odnosima moći, pravilima i kontroli unutar potkulturnih grupa. Istraživanje Vilijama Cicosa (Tsitsos 1999) ukazalo je na mogućnost da ideologija, odnos prema pravilima, pristup kontroli i dominaciji utiču na različite motive i oblike učestvovanja u ,šutki”. Treći krug analize dotiče se odnosa centra i margine, hegemonije (pot)kulture i , šutke" kao transgresivnog prostora manifestovanja individualnih identiteta. Koristan reper za ovaj nivo analize predstavlja studija grupe autora: Gabrijele Ričis, Breta Lešua i Karla Spraklena, koji su se bavili analizom narativa i posmatranjem učesnica „šutke” unutar ekstremne metal scene u Lidsu (Riches, Lashua, Spracklen 2014). Kroz pomenute analize nastojim da razumem koji su to faktori koji održavaju grupni ili međugrupni ekvilibrijum i sprečavaju da načelno haotičan i grub ritual eskalira u nasilje. Pored navedenog, ova analiza nastoji da doprinese razumevanju odnosa potkulture i šireg društva. 
Na početku sam istakao koncept opservacije sa participacijom kao metodološko oruđe koje pomaže da bolje razumem dubinu rituala. To ne znači da drugi autori, koji nisu učestvovali, ne mogu analizirati „šutku”, ali mislim da je za dubinsko razumevanje ovog rituala pored teorije i eventualnog posmatranja na koncertima ili video snimcima, bitan i pristup čulne antropologije koja vas postavlja u centar zbivanja. Smatram da neke zaista intimne aspekte rituala neko ko nije učesnik ne tumači na isti način kao istraživač koji ima iskustvo učestvovanja. ${ }^{9}$ Primera radi, Krejg Palmer primenjuje teoriju uzajamnog altruizma (Trivers 1971) i teoriju zahtevne signalizacije na dva rituala: ,poklade" u Finskoj i ,šutku” na pank koncertima. Kroz pomenutu prizmu Palmer „šutku” vidi kao ritual sticanja i potvrde poverenja, a praksu podizanja palih učesnika označava kao suštinsku za stvaranje socijalnih veza unutar grupe. S ovom tvrdnjom se načelno slažem. Ipak, autor to posmatra kao mehanički akt čija je funkcija korist ostalih učesnika, koji tako izbegavaju prepreku tj. smanjuju šansu da se drugi povrede (Palmer 2005, 158). Takav pogled na pomenutu praksu čini mi se jednodimenzionalnim. Naime, iako je čin podizanja palih učesnika po grupu u ,šutki” nesumnjivo praktičan, pomoć drugih učesnika i osećaj sigurnosti individue u srcu haotičnog kretanja takođe doprinosi sticanju poverenja, zauzimanju pozicije pojedinca u grupi, reprodukovanju pomenutog gesta, a time i jačanju socijalnih veza. Ovo razumeju i drugi učesnici ,šutke” i hrle u pomoć palom pojedincu, ne nužno iz praktičnog razloga dobrobiti drugih učesnika, već i kako bi manifestovali/reprodukovali usvojene obrasce grupne solidarnosti. Na taj način, kroz individualno iskustvo i grupnu solidarnost, postiže se saobraženje individualnog s identitetom kolektiva. Drugim rečima, taj akt je u teoriji logičan pokazatelj koristi grupe u odnosu na pojedinca, ali je u praksi nešto drugačije, jer je grupni trud usmeren dobrobiti individue kroz šta se nadograđuju unutargrupni odnosi. Gabrijela Ričis i Fransis Morton ističu važnost upravo „mošografije” kao specifičnog metodološkog pristupa. Ričis i Morton navode kako je ova metaforička praksa i transgresivna potkulturna forma ekspresije bitna jer se koncentriše na čulne, neverbalne i afektivne aspekte performansa u kom se učestvuje i koji se istražuje (Riches 2014,

9 Kao dugogodišnji učesnik ,,andergraund” koncerata, što kao izvođač što kao deo publike/posmatrač, dakle, deo potkulture koju u ovom članku analiziram, svestan sam da se nameće pitanje moguće ,epistemičke povlašćenosti”. Pored uticaja koji epistemička povlašćenost ima na saznajni proces, otvara se i pitanje ,sindroma dvostrukog pripadnika" tj. pitanje uticaja pripadnosti određenoj grupi na političko, etičko ili drugo ideološko pozicioniranje istraživača (Naumović 1998, Milenković 2010, Kulenović 2011). Smatram da su pomenuta pitanja važna i planiram da ih razradim u narednim radovima. 
Morton 2006). Pored učestvovanja, opservacija ponašanja na koncertima, kako u šutki tako i u odnosu na nju, takođe je bitan način sakupljanja informacija koje govore o različitim odnosima u prostoru i odnosu ostalih na koncertu prema ritualu koji se odvija. Ovaj deo istraživanja sam sprovodio kako na koncertima, tako i kroz gledanje video snimaka koncerata. Sakupljanje iskaza putem intervjua s učesnicima, s ljudima koji imaju neutralan, ali i onima koji imaju negativan stav o fenomenu, obavljao sam kroz dubinske i neformalne razgovore. ${ }^{10}$ Neformalnih intervjua je bilo više nego formalnih budući da su formalni razgovori često rezultovali dobijanjem odgovora koji odražavaju okvir ideja i obrazaca potkulture u njegovoj idealnoj ili idealističkoj formi. ${ }^{11}$ S druge strane, kroz spontane, neformalne intervjue dobio sam pristup stavovima koji su bili iskreniji i korisniji. Pored intervjua koje sam sprovodio uživo, koristio sam se i pogodnostima virtuelnih društvenih mreža. U specijalizovanim grupama na fejsbuku poput npr. grupe „metalci” čiji su članovi, pored ljubitelja hevi metala, i pankeri, hard korovci i drugi, postavljao sam pitanja o motivima učestvovanja ili specifičnostima ,šutke" u nekoliko navrata. Odgovori ispitanika na pomenutim virutelnim platformama su potvrdili neke konstante koje odražavaju ideal univerzalnog poštovanja, saradnje, jedinstva, nenasilja ili prava svih da jednako učestvuju u sceni, na koncertu ili u ,šutki”. Ovo je zanimljivo jer, kao što će se kasnije u članku pokazati, zapravo predstavlja manifestni stav karakterističan za predstavnike potkultura, dok praksa, u nekim slučajevima, ukazuje na kontradiktorno ponašanje. Upravo zbog toga je bilo zanimljivo sučeljavati ispitanike na društvenim mrežama koji su ulazili u debate ukazujući time na diskrepenciju između očekivanog, idealnog odogovora i stvarnosti. Navedeni metodološki pristup je važan za ideju ovog članka čiji je cilj, između ostalog, sagledati realan odnos homogenosti i heterogenosti, tenzija unutar potkulturnih grupa, te saznati koja su to univerzalna a koja mesta konflikta ili društvene drame.

${ }^{10}$ Zbog intimnosti teme na kraju rada navodim samo deo ispitanika punim imenom, nadimkom ili inicijalima, dok je deo ispitanika želeo da ostane anoniman. Želja za anonimnošću posledica je, pretpostavljam, eventualnog ulaženja u sukob mišljenja ili debate s drugim članovima grupa, ili jednostavno, želja da se pojedinac ne eksponira van ustaljenih medijskih prostora poput fanzina ili webzina. Zanimljivo je da su iskazi dobijeni uživo ili unutar specijalizovanih grupa na fejsbuku često bili mnogo više politički korektni nego što je to ranije bio slučaj na internet forumima namenjenih istoj populaciji. Razlika između dve platforme, socijalne mreže poput fejsbuka i foruma je u relativnoj anonimnosti, koju učesnici debata imaju na forumima.

${ }^{11}$ Pod ,idelnim” ili „idelističkim” odgovorima misli se na odgovore koji odražavaju privrženost teorijskoj opštoj ideji potkulture po uzoru na često idealizovanu Zapadnu scenu. Ti odgovori su često bili u diskrapenciji sa stvarnim stavovima ispitanika a još češće sa „stanjem na terenu”. 


\section{Šta je to „šutka” i kako se ona izvodi?}

Odmah na početku moram ukazati na terminološki problem. Pre svega, termin ,šutka” zapravo ne odgovara kao opis svih telesnih tehnika i prostornih kretanja koje se praktikuju na koncertima. „Šutka” kao specifičan termin označava „skankovanje”, vrstu plesa koji uključuje i blago šutiranje i sudaranje učesnika, ali to nije isto što i „skakanje sa bine”, „, slemovanje” ili „mošovanje”. Ipak, ova odrednica je odabrana kao „kišobran” termin zbog toga što on u narativima ispitanika označava skup različitih načina učešća na koncertu. Na pitanje „kako” se učestvuje u „šutki” ili kako se ona izvodi, odgovoriću kroz kratak opisni pregled razvoja telesnih tehnika koje čine ovu praksu. Pregled ovih praksi navodim počev od starijih ka novijim.

„Pogo”. U dokumentarnom filmu Džulijana Templa „The filth and the fury", ${ }^{12}$ o engleskom pank bendu Sex Pistols, Sid Višiz ${ }^{13}$, basista benda i jedan od simbola pank pokreta, tvrdio je da je upravo on izmislio ovu vrstu plesa. Višiz navodi da mu je na jednom koncertu bilo dosadno da pasivno gleda bend na bini, kakva je do tada bila praksa na koncertima, pa je počeo da skače u mestu poput deteta na „pogo štapu”. Naravno, vrlo brzo je došlo do sudaranja s drugim gledaocima. Na istom koncertu neki ljudi su počeli da ga oponašaju, a potom se ta praksa počela javljati i na drugim pank koncertima. Iako najpre individualni čin, koji je mogao biti tumačen i kao oblik nasilja, „pogo” ubrzo postaje deo pank plesa, odnosno folklora. U intervjuima s članovima beogradskih grupa Šaht, Thrashagain i Heller, istaknuto je da su prvi pank, metal i hard core koncerti u kultnom prostoru pozorišta Dadov u Beogradu bili podeljeni na bend koji nastupa i publiku koja stoji ili sedi i posmatra. Vrlo brzo su domaći pankeri i metalci preuzeli novi zapadni trend izvođenja ,šutke" na koncertima i skakanja sa bine u publiku. „Đubre”, pevač Thrashagain-a, rekao mi je da je prvi put skakanje u publiku i haos na koncertima video u Ljubljani. Ispitanik navodi da je određen broj ljudi osamdesetih godina prošlog veka počeo da dolazi na koncerte upravo da bi video ,šutku” i učestvovao u koncertu na nov način. Naravno, devedesetih godina prošlog veka pripadnici potkultura su bili već dobro upoznati s trendovima na Zapadu, i ponašanje na koncertima je pratilo novine u ponašanju na velikim svetskim scenama poput britanske, američke, nemačke, finske ili japanske. „Skankovanje” je jedan od oblika učestvovanja pri kom pojedinac zapravo pleše tako što dramatično izdiže kolena i lakta se, pri čemu se neretko desi da šutne ili gurne drugog učesnika iako to nije cilj ove prakse. Stariji pripadnici Oi i skinhead scene su mi ispričali kako su u nedostatku specifičnih

12 http://www.imdb.com/title/tt0236216/Preuzeto 19. 6. 2014.

13 Sid Višiz (Sid Vicious) je nadimak, pravo ime mu je bilo Sajmon Džon Riči (Simon John Ritchie). 
pank koncerata oni odlazili na veće koncerte (Partibrejkersi, Toni Montano) i tu skankovali, a neretko i agresivno šutirali druge učesnike ,šutke”. Ali ne sve. Poznanike sa „scene” ovi učesnici nisu napadali već je tada „šutka” bila performirana kao ples.

„Slemovanje / Slam dancing” je način učestvovanja u „šutki” koji je specifičan za razvoj hard kor pank pokreta u Americi i svetu počev od osamdesetih godina prošlog veka. Izvođenje „slem densinga” podrazumeva da se određeni broj ljudi u centru koncertnog prostora kreće u pravcu suprotnom od kazaljke na satu. Na ovaj način se formira dinamični obruč koji se sastoji od ljudi koji guraju jedni druge i dramatično zamahuju rukama. U početku su se učesnici kretali u krug u pravcu i ritmu muzike, mahali rukama ispred i iza sebe, delom prema onima koji su im fizički blizu delom prema drugima van kruga. Zamahivanje rukama je zapravo deo dramatizacije a vrlo retko predstavlja gest koji za cilj ima da se neko udari ili povredi. Iako ,slemovanje” obično podrazumeva kružno kretanje, neretko se formira krug a učesnici haotično trče kroz njegov centar od jedne tačke u njegovom prečniku do druge, sudarajući se s drugim učesnicima.

„Moš pit / Mosh pit”. Ova, čini se, ekstremnija, grublja verzija plesanja i grupnog kretanja razvila se uporedo s razvojem energičnije i agresivnije verzije punk scene, s hard kor pankom („hard core”) u Americi. Tu vrstu plesa razvili su i popularizovali ljudi koji su u Vašingtonu pisali fanzine, organizovali koncerte ili svirali u grupama poput „Minor threat”, „Scream”, „Bad brains”, a u Kaliforniji, „The dead Kennedys” i „Circle jerks”, itd. Iako se ova pojava u fanzinima označavala kao „mash” izgovarala se kao „mosh” i podrazumevala je upravo frentično sudaranje ljudi u zanosu. Thrash ${ }^{14}$ metal, hard kor ili krosover bendovi, poput S.O.D i „Anthrax”, popularizovali su termin koristeći ga u pesmama, npr. „Milano mosh” (1985) ili „Caught in a mosh”(1987), isto su radili i bendovi „The Melvins”, „Black flag” i drugi. Iako su naziv i praksa u početku bili zastupljeniji u hard kor pre nego u metal potkulturi, u periodu ranih osamdesetih došlo je do udruživanja poštovalaca ovih pravaca ${ }^{15}$ a time i širenja novog oblika šutke. Odnos prema prostoru je nekad promenljiv tako da je nekad bitno da sredina kruga bude prazna a nekad popunjena. Savremeni oblik izvođenja ove prakse podrazumeva da se učesnici rasporede a potom u ritmu muzike krenu da izuzetno jako i agresivno mašu nogama i rukama poput karatista, pritom se ne dodirujući. Fizički kontakt se često izbegava budući da usled sudaranja uče-

${ }^{14}$ Podžanr metala karakterističan po brzom tempu pesama i satanističkoj, antireligijskoj ili političkoj pozadini tekstova. Thrash je zapravo hevi metal koji je preuzeo neke elemente ideologije pank pokreta i muzike.

15 Saobraženje različitih potkulturnih muzičkih pravaca npr. thrash metala i hard kor panka, obično se naziva krosover (crossover). 
snika dolazi do povreda. Razlika između mošovanja i slemovanja je u tome što je slemovanje više grupni a mošovanje individualni princip učestvovanja, gde je moš sporija ali i agresivnija verzija slemovanja. Iako je ova nova vrsta plesa postala jako popularna, ubrzo se ispostavilo da pored velikog broja mladih koji učestvuju u izvođenju postoji i određen broj povreda koje izgleda prate takve koncerte (Pogrebin 1996). ${ }^{16}$

„Kružna šutka / circle pit”. Kao što smo pomenuli, izvorni oblik kružnog kretanja i dramatičnog mahanja pesnicama ili rukama, Slem dens, menjan je vremenom tako da su se pojavile i nove forme izvođenja. „Srkl pit” (Circle pit), ili kružna jama, može podrazumevati različite načine ponašanja, od kružnog kretanja gde učesnici zamahuju rukama i nogama do trčanja u krug. ${ }^{17}$ Naime, u novijem periodu, neretko bend planski osmisli tkz. „brejk”, spori ili brzi deo pesme koji motiviše slušaoca i učesnike koncerta da se ponašaju na određen način. $U$ tom trenutku, često na poziv benda sa bine, deo publike počinje da trči praveći kružnu putanju dok centar kruga ostaje prazan. U trenutku kada nastupi (poznati, očekivani) agresivni deo pesme, atmosfera je na vrhuncu, učesnici doživljavaju katarzu i svi uključeni u trčanje skaču jedni ka drugima, guraju se i sudaraju (Silverberg, Bierbaum, Matthew, James, Cohen, Itai 2013). Ovakvo ponašanje je pre prisutno na većim koncertima i festivalima nego na lokalnim andregraund koncertima. Sličan primer prakse proistekle iz andergraunda a karakteristične za velike koncerte jeste „Zid smrti / Wall of death”. Ova praksa se oslanja na komunikaciju benda i publike, gde se na poziv benda publika razdvoji na dve strane da bi, u ključnom trenutku, dve strane potrčale jedna prema drugoj i sudarile se.

„Jahanje publike / Crowd riding” i ,Skakanje sa bine / Stage Dive”. ,Jahanje publike" predstavlja stariji oblik učestvovanja u hard kor pank koncertu. Kao i veći deo praksi iz ovog korpusa, i on predstavlja običaj koji je spontano nastao a koji se zadržao do danas. Početkom osamdesetih godina bilo je uobičajeno videti kako publika nosi druge učesnike na rukama iznad svojih glava ili na ramenima. Učesnici koje publika nosi tu su dospeli na dva načina: ili su se zadržali nakon skoka sa bine (praksa koju ću opisati u narednom pasusu) ili su se na svoju ili tuđu inicijativu na druge učesnike praktično uzdigli sa zemlje.

${ }^{16}$ Nekoliko bendova i muzičara poput npr. „Fugazzi-ja” čiji je član Ian MekKej, jedan od inovatora američkog hard kor-a, ,strejt edž” pokreta, pa i same „šutke”, stalo je protiv nastavljanja i širenja ovakvog ponašanja upravo zato što su koncerti postajali sve opasniji ili nasilniji. http://bandwidth.wamu.org/stage-diving-and-violence-at-showswhats-a-band-to-do/ Preuzeto 15. 5. 2018.

${ }_{17}$ Ovakvu praksu sam primetio na koncertu nemačke grupe Tankard u Solunu. U Srbiji nije neuobičajeno da publika trči u krug, ali je gotovo pravilo da šutka predstavlja uobičajeni oblik učestvovanja u grupnom plesu. Za delove Grčke u kojima sam posećivao koncerte publike ima više i veliki broj ljudi gotovo sinhronizovano trči u pravcu kontra od kazaljke na satu. 
Ukoliko na koncertu vlada veliko uzbuđenje, energija počinje da se oslobađa kroz šutku, što doprinosi atmosferi koncerta. Tada se događa da pojedinci svoj entuzijazam iskazuju tako što izvode ovu svojevrsnu vratolomiju. Kada neko želi da se „popne” na druge učesnike, obično da znak svojim poznanicima koji pritrče, podignu ga na ramena a potom i polože celom dužinom tela na podignute ruke ili ramena publike. Postoji i opasnija verzija, jahanja" publike, a to je skakanje u publiku sa bine (stage dive). Kao što sam pomenuo, skakanje sa bine je jedan od najspecifičnijih i danas zastupljenih poteza na koncertima. Osnovna ideja je da pojedinac provede jedan kratak deo vremena u vazduhu za vreme dok bend svira, i to između benda i publike. ${ }^{18}$ Bez obzira na to da li postoje barijere, tj. zaštitna ograda koja deli stranu koja svira i stranu koja gleda, neki učesnici koncerta često preskaču ove barijere, penju se na binu a potom skaču u publiku. Postoji više varijanti samog skoka, u zavisnosti od toga da li je prisutno obezbeđenje ili ne, učesnik provodi malo vremena na bini sa koje se zaleti i skoči na glavu, leđa, ruke ili noge. Tu su naravno i primeri onih koji pokazuju fizičku spretnost tako što rade salto u publiku ili slične (svakako opasne) egzibicije.

Ako pažljivo pročitamo opise praksi koje čine,,šutku" jasno je da se radi o gruboj praksi koja nosi određen stepen opasnosti po učesnike. U tom smislu, možemo razumeti zašto su video snimci ove prakse ostavili nagativan utisak na posmatrače koji su viđeno opisali kao „,nasilje i haos”. U narednom delu rada nastojim da dam uvid u to koliko je ova ritualna praksa zapravo kompleksna, te da je nasilje pre posledica devijacije u simboličkom učestvovanju nego konstanta.

\title{
„Šutka”: socijalizacija kroz ideologiju bunta
}

\begin{abstract}
„Ako se mora izabrati politička strana, pankeri su uglavnom anarhisti... (ipak, za političke pankere) anarhija ne znači jednostavno odustvo zakona, već odsustvo potrebe za zakonima... Anarhija podrazumeva individue koje se ponašaju odgovorno... politički pankeri žele društvo u kom red nije nametnut od spolja već uspostavljen iznutra"
\end{abstract}

\section{Craig O’Hara (O’Hara 2001)}

Budući da sam u prethodnom poglavlju dao odgovor na pitanje kako se ,šutka" izvodi, treba pojasniti gde se ova praksa izvodi, ko je izvodi i zašto.

18 Moram napomenuti da se u ovom članku ne bavim ulogom muzičkih grupa koje potpomažu stvaranju ,,atmosfere”, odnosno konteksta koji pogoduje izvođenju različitih formi ,šutke”. Mogućnost indukovanja, sputavanja ili koordinisanja „šutki” od strane članova muzičkih grupa, ili ,šutke” kao manifestacije odnosa ,publike” i ,benda”, kao muzičkom i ideološkom formacijom svakako je izuzetno važan element priče o ,šutki” ali prevazilazi obim ovog rada. 
„Andergraund koncert” je ne samo fizički već i simbolički prostor. Andergraund kultura (Stanojević 2008) ili „scena” (Stanojević 2013) bitne su odrednice koje ispitanici često ističu, a koje označavaju različite alternativne pristupe kulturi, promišljanju stvarnosti, pripadanju, etici i delovanju. Pripadnici potkulturnih i ,,andergraund” pokreta često sebe pozicioniraju opozitno ili čak antagonistički u odnosu na „mejnstrim kulturu”. Pozicioniranje pripadnika potkulture u odnosu na „mejnstrim”, po dobijenim iskazima, često je posledica ili odsustva osećaja prihvaćenosti i pripadanja pojedinca, ili obrnuto, izbora pojedinca koji se usled neslaganja sa načinom života, idealima i pravilima ponašanja mejnstrim društva, pronalazi u potkulturi. Tako je osnovna ideja pank, hard kor, metal, grajnd i drugih andergraund pokreta u distanciranju u odnosu na vrednosti, stil, način razmišljanja i ponašanja šireg društva koje, kroz muziku, način oblačenja, ponašanja itd, kritikuju i preispituju. Ovo Cicos naziva ideologijom bunta ili pobune (Tsitsos 1999, 400). U tom smislu, koncerti kao „mejnstrim spektakli” razlikuju se od DIY ${ }^{19}$ i andergraund koncerata, kako po svojoj formi, tako i po organizaciono-ekonomskom pristupu, načinu ponašanja na koncertu, kao i u dijalektici na nivou izvođač - publika. Tehnički, jasno je da i na andergraund koncertima postoji izvođač kao što postoje i gledaoci, ali princip interakcije ne samo da nije isti kao u mejnstrim kulturi, već ga često preispituje. Osnovna razlika između dva pomenuta pristupa organizaciji i učestvovanju u koncertu jeste ta što za razliku od mejnstrim koncerata, gde je prostor unapred mapiran i podeljen na prostor za konzumente, publiku i muzičku grupu, a te simboličke granice jasno su podeljene ogradama uz prisustvo predstavnika (državnih) institucija, andergraund koncerti često nemaju ograde pa ni obezbeđenje, a u nekim slučajevima ni binu..$^{20}$ Može se reći da je andergraund koncert neka vrsta relativno nezavisnog, samoupravnog kolektivnog truda, makar u idealističkom smislu. Naravno, ovo se može pripisati tehničkim okolnostima u kojima se pank ili metal koncerti održavaju, ali postoji jedna bitna razlika. Andergraund scene po ideji nastoje da kroz koncerte ne manifestuju odvojenost, hijerarhiju ili elitizam, već jedinstvo potkulturne grupe, pogotovo zbog toga što je veliki procenat pripadnika „publike" zapravo i deo muzičkih grupa koje sviraju pred tom istom publikom. Cilj

19 DIY - „Do It Yourself / uradi sam” je princip organizacije koncerata, izdavaštva, alternativnih medija i načina socijalizacije koji su jako važni za pank, metal i druge, zasnovane na ideji nezavisnosti u odnosu na pravila, uticaj i sistem šireg društva.

20 Koncerti 80ih i 90ih u Beogradu delili su se na velike, mejnstrim koncerte koji su se održavali npr. na Tašmajdanu, koncerte većih stranih grupa (npr. The Exploited, SKC 1984), ili lokalne u mesnim zajednicama a kasnije u prostorima Dadova ili KST-a. Ispitanici su isticali kako je i u Dadovu postojala volja za „šutkom” i skakanjem u publiku iako se radi o prostoru pozorišta, ali i da je izvođenje ove prakse u publici često prekidalo onu na bini, tj. „šutka” je dovodila do prekidanja koncerata od strane obezbeđenja. 
koncerata i muzičkih grupa andergraund i DIY opredeljenja po definiciji nije prelazak u mejnstrim muzičku scenu, niti prilagođavanje stila i pristupa ukusu masovnog društva. Pank i metal bendovi nastupaju kako u skvotovima, ${ }^{21}$ tako i u prostorima koji se iznajmljuju za koncerte i imaju fizičke barijere između izvođača i publike, ali barijere u ovim slučajevima samo načelno služe svojoj uobičajenoj svrsi, dok je mnogo važnija njihova uloga u preispitivanju, odnosno negiranju ustaljenih načina podele prostora ili kategorija učesnika. Za razliku od mejnstrim koncerata, kršenje pravila, odnosno prelazak publike iz jednog u drugi deo simboličkog prostora, preko fizičkih barijera ograde ili bine, ne samo da se ne posmatra kao loša stvar već kao suštinski bitna za saobraženje dva dela performansa, izvođača i gledaoca. Primera radi, učesnik koji se penje na binu i skače s nje prelazi liminalni deo prostora i, negiranjem barijere između publike i izvođača, on, bend na bini i publika, koja ga nakon skoka hvata, podržavaju čin koji demonstrira slamanje simboličnih granica koje razdvajaju kategorije ili klase učesnika koncerta ili scene. Drugim rečima, organizacija prostora koncerta može biti metafora za kontrolu i održavanje poretka u društvu, odnosno opozicija mejnstrim ideologiji ili kulturi. „Ideologija” i „pobuna” su ključne reči. Termin ideologija u kontekstu potkultura može imati više od jednog značenja. Usvajam shvatanje ideologije kao pokreta ili sistema zasnovanog na političkim idejama, društvenom i kulturnom diskursu iz kog dalje proističe etika ponašanja i socijalizacije, „Ideologija pobune” potkultura takođe je neka vrsta drugačijeg pogleda na svet ili kritika i otpor postojećem. I zaista, „drugost” potkulture ne mora ni biti zasnovana na političkim idejama per se, koliko je samo postojanje grupa koje neguju često potpuno opozitnu etiku, poglede na svet i stvarnost, samo po sebi ideološka opozicija vladajućem poretku. ${ }^{22}$ Primera radi, ideologija apolitičnih pankera ne mora biti zasnovana na političkoj ideji već može počivati na preispitivanju pravila i ustrojstva šireg društva koje zamenjuje haosom i odsustvom pravila, npr. dokolicom i opijanjem kao idealom. Ipak, preispitivanje politike društvenog ustrojstva kao ideala svakako je politički koliko i društveni akt.

Potkulturu, „,scenu” ili ,šutku” kao koncepte možemo posmatrati i kroz prizmu globalizacije, te odnosa svetskih trendova i njihovih lokalnih inkarnacija (Žikić 2012), kojima je zajednička antisistemska ili kontrakulturna ideologija, ali pre svega konstanta socijalizacije kroz bunt. Socijalizacija na najširem nivou

${ }^{21}$ „Skvot” je postojeći, često napušten objekat, čini je prostor (simbolički) „okupiran” od strane, u ovom slučaju pankera koji prostor adaptiraju i koriste u svrhu održavanja određenih kulturnih dešavanja, ali i stanovanja.

${ }^{22} \mathrm{O}$ direktnoj sukobljenosti potkulture i vladajuće ideologije svedoče i iskazi beogradskih pankera i metalaca koji su osamdesetih godina prošlog veka bili prepoznati kao opasni, strani elementi ili pretnja postojećem sistemu, i ne samo da ih je okolina osuđivala, već ih je i milicija maltretirala. 
i mobilizacija zasnovana na različitm ideologijama nisu nezavisne već povezane. Da bi mogli dekonstruisati ,šutku” kao ritual manifestacije ideologija, moramo prvo objasniti način na koji on funkcioniše kao plato za socijalizaciju. Već pomenuti Krejg Palmer u svom članku pravi analogiju između poklada u Finskoj i ,šutki" na pank koncertima. Po Palmeru, ova dva rituala povezuje mehanizam prevazilaženja stalnog socijalnog konteksta i načina promišljanja sebe i drugih u cilju ostvarivanja novih ili nadograđivanja postojećih socijalnih veza (Palmer 2005, 163). Palmer se oslanja na teoriju uzajamnog altruizma i teorije zahtevne signalizacije (Atran 2002), te objašnjava kako neki rituali na komunikacijskom nivou pomažu uspostavljanju poverenja i posvećenosti u dugoročnim ko-operativnim vezama (Palmer 2005, 159). Ovi rituali iziskuju određenu vrstu predanosti ili požrtvovanost (npr. vreme, energija, bol) u cilju postizanja većeg dobra. Lične žrtve signalizuju kolektivu privrženost pojedinca. Dalje saobraženje grupe i pojedinca obavlja se kroz ritual u kom pojedinac postavlja sebe u situaciju gde je izložen potencijalnoj opasnosti u odnosu na druge učesnike rituala. Učesnici poklada u Finskoj oblače kostime i bez poziva ulaze u kuće jedni drugih. Ovaj ritual odražava vekovni strah od najezde stranaca, pirata ili odbeglih mornara. Svi učesnici rituala trpe da im se u određenom vremenskom periodu ugrozi privatni prostor, ne samo kuće u koju ulaze maskirani ljudi, već i lični, telesni prostor budući da nepozvani gosti često začikavaju i dodiruju tela domaćina i njegove žene. Domaćini ipak na ovo ne reaguju na način na koji bi inače branili svoj posed ili privatnost, tj. ne uzvraćaju silom, ali koriste pravo da kroz sistem pitanja potencijalno otkriju identitet maskiranog čoveka. U tom smislu, ritual za cilj ima ili potvrdu bliskosti članova zajednice ili nadogradnju, budući da se kroz sistem pitanja i odgovora dolazi do sticanja šireg znanja o ličnosti. Takođe, kroz izbegavanje uobičajene defanzivne reakcije, tj. nasilja, stvara se poverenje između dve strane, odnosno bliskost (Palmer 2005, 158). Na vrlo sličan način funkcioniše i socijalizacija kroz, „šutku”. U specifičnom prostoru i vremenskom periodu nastaje ono što neupućeni posmatrači nazivaju „haosom” ili ,anarhijom - odsustvom pravila”. S druge strane, budući da je način učestvovanja energičan i grub, postoji opasnost od fizičkog kontakta ili povreda, a ipak, nasilje najčešće izostaje. Ono što je presudno za ojačavanje socijalnih veza jeste momenat $u$ kome oba učesnika u konfliktu zastanu i ne odreaguju na grubost ili ugrožavanje ličnog prostora na način na koji bi to uradili van koncerta, u kontekstu šireg društva, a to bi vrlo verovatno bila eskalacija u nasilje. $\mathrm{Na}$ ovaj način potvrđuje se spremnost da zarad grupnog dobra, individualni bol bude marginalizovan. Kroz pomenuti ritual poverenja stvara se bliskost među članovima grupe. Ovakvo ponašanje karakteristično je za ono što Tarner naziva „komunitas” (Turner 1974) kao konceptom dela društva u liminalnoj fazi, dakle relativno nezavisnog u odnosu na pravila šireg društva. Palmer ističe teatralnost „šutke” koja, iako po svojoj formi haotična struktura, funkcioniše po principu 
„nepisanih pravila”. Autor navodi u ovom radu ranije navedeni primer podizanja palih učesnika. Po iskazima mnogih ispitanika pravilo je da ako neko padne, svi u blizini moraju da priskoče u pomoć i podignu ga. Palmer u ovom gestu vidi mehaničku reakciju koja služi manje individui koja je na podu a više kolektivu, tj. drugima koji se neće saplitati o njega i time izbeći dodatne povrede. Iako takva reakcija nesumnjivo pogoduje i drugim učesnicima, gest je takođe uperen i prema pojedincu. Ostali učesnici istog trenutka priskaču u pomoć demonstrirajući time jedinstvo scene i prepoznatu pripadnost učesnika. Kroz takve gestove potvrđuje se postojanje „nepisanih pravila” koja učesnici poštuju i nadograđuju, i u odnosu na koja deluju. Ovo svakako doprinosi osećaju sigurnosti, povezanosti i saradnje kroz koju se grupnim trudom kreira stvarnost i odnosi moći naizgled drugačiji od onih u spoljnjem svetu.

Ako prethodni primer daje uvid u način socijalizacije i potvrde socijalnih veza kroz obrasce poželjnog načina učestvovanja u koncertu kao platou komunitasa (Turner 1977), naredna ilustracija ukazuje kako se ove veze iznova potvrđuju. Kada pojedinac skače sa bine, on to često radi na najopasniji i najmanje promišljen način. Pri skoku sa bine u publiku, onaj koji skače to čini tako što, bez previše gledanja, skače s ivice bine prema publici i to često okrenut leđima. ${ }^{23}$ Ovaj gest je svakako opasan jer ne samo da može dovesti do težih povreda, već i do smrti onog koji skače. ${ }^{24}$ Ipak, skakač to čini i pada na već spremne šake publike, izazivajući opšte oduševljenje. Ovu ritualizovanu praksu bi mogli nazvati ,skokom vere” (leap of faith ${ }^{25}$ ) budući da ona odražava upravo veru u vrednosti i povezanost koju deli grupa. Pomenuti ritual potvrđivanja međusobne povezanosti i poverenja ogleda se u ushićenju okupljenih, koji ne samo da hitaju sa svih strana kako bi pridržali telo skakača, već da bi ga dodirnuli i time manifestovali svoju privrženost ideji (grupnog ali i globalnog) jedinstva. Ono što je zapravo zanimljivo je to što se skakač i veći deo publike

${ }^{23}$ Onaj koji skače sa bine može skočiti i na stomak, ruke ili noge/kolena, ali u tom slučaju postoji šansa da ga publika neće uspešno dočekati ili da će povrediti nekog u publici. Jedan takav primer je Đubre, pevač beogradskog hard kor benda Trashagain.

${ }^{24} \mathrm{http}: / / \mathrm{www} \cdot$ blabbermouth.net/news/swiss-man-dies-after-stage-diving-atsuicidal-tendencies-concert/ i http://www.blabbermouth.net/news/fan-reportedly-diesafter-stage-diving-at-miss-may-i-concert-in-new-york-city/ Preuzeto 15. 5. 2018.

25 „Leap of faith” bi mogli prevesti kao „skok vere” ali i „skok poverenja”. Kao i prevod, pomenuti gest ima dve slične ali ipak različite konotacije. S jedne strane „skok poverenja" bi bio zasnovan na odnosu između skakača i onih koji ga dočekuju tj. po naučenoj akciji i očekivanoj reakciji u kontekstu lokalnog (poznatog). S druge strane, ukoliko npr. skakač izvede ovu figuru na naučeni način ali u nepoznatom kontekstu (npr. koncert u drugoj državi), radi se ne o poverenju koje on ima u druge učesnike po principu poznanstva i bliskosti, jer ono ne postoji, već o ,veri” u osnovna, globalna pravila po kome pripadnici svih scena isto reaguju na određeni skup akcija. 
koja ga hvata ne moraju poznavati od ranije, bitno je da postoji ideja i vera u zajedničke (na ovom nivou globalno raširene) potkulturne vrednosti koje se ispoljavaju kroz ritual skakanja, odnosno hvatanja skakača potvrđujući time potkulturnu verziranost grupe i pojedinca. U radu prethodno pomenute grupe autora o „mošografiji” naveden je iskaz jedne od učesnica koja ilustruje prethodnu konstataciju: „u jednom trenutku uhvatiš nečiji pogled na dve sekunde, i tih dve sekunde ste najbolji prijatelji... potom se popneš na binu i ponovo uhvatiš pogled ljudi u publici, i znaš da će te uhvatiti... onda skočiš i znaš da će sve biti sjajno" (Riches, Lashua, Spracklen 2014, 96). Ovakvo rezonovanje je uobičajeno na nivou lokalnih scena i koncerata gde postoji manja ili veća bliskost između pripadnika. S druge strane, potkulturni obrasci ponašanja i vrednosti, ali i sistemi socijalizacije često su globalno rašireni. Za Palmera je socializujući aspekt, „štke” presudan. Ipak, za ovu analizu to je samo početak u razumevanju odnosa unutar grupe, i odnosa potkulture, (lokalne, dominantne) kulture i društva. Kao što sam pomenuo u uvodnom delu rada, iskazi ljudi koji nisu upoznati s obrascima ponašanja u potkulturnim grupama doživljavaju ritual ,šutke" kao prosto nasilan i haotičan. Ovo je razumljivo budući da posmatrači percipiraju taj ritual koristeći „kulturne naočari” dominantne kulture kroz koje naizgled haotičan i grub koncertni ritual izgleda kao negacija „civilizovanih" oblika socijalizacije, suživota i vrednosti. Za pripadnike potkultura, sistem vrednosti, hijerarhije, pravila i kontrole koji potiču iz tradicionalnih ili savremenih društveno-političkih institucija šireg društva često biva prepoznat kao oblik represije, proistekao iz odnosa moći u kojim je „mali čovek” na dnu hijerarhijske lestvice. Ukoliko se na ovaj način posmatra odnos kulture i potkulture, razumljivo je što određeni aspekti potkulturnog bivstvovanja izgledaju kao potpuna inverzija društvenih vrednosti. Ipak, ono što se čini kao inverzija može biti samo deo grupne dramatizacije. Dramatizacija je ključna reč budući da, kako to Cicos ističe, čak i mahanje pesnicama ima više teatralnu nego antagonističku funkciju (Tsitsos 1999, 403). Učesnici koji „slemuju”, kreću se u krug i zaista zamahuju rukama odnosno pesnicama, ali je luk udarca zapravo usmeren izvan kruga a ne upućen učesnicima. Drugim rečima, iako grub, gest nije nasilan. Ovakvo ponašanje, kao uopšte i korišćenje simbola, gestova, stila odevanja, izražavanja pa i sviranja u potkulturnoj matrici odražava ono što Lul naziva ,paradoksalnim simbolizmom” (Lull 1987, 202). To bi značilo da, iako pripadnici potkultura mogu delovati opasno ili antagonistički, u pitanju je ipak izvrnuta simbolika ,spoljnog sveta”, koju često ne prati i istovetno ponašanje unutar grupe, tj. jednih prema drugima.

If you've come to fight, get outta here, you ain't no better than the bouncers We ain't trying to be police, If you ape the cops it ain't anarchy Jello Biafra (Dead Kennedys) 
„Šutka” kao i „scena” često su u iskazima percipirani kao prostor slobode iskazivanja individualnih afiniteta bez jasnih ili makar fiksiranih pravila, odnosno kao haos. Pravila ipak postoje. Dva navedena primera, podizanje palih učesnika i zajedničko prihvatanje onih koji skaču sa bine, odražavaju postojanje korpusa nepisanih pravila. Ispitanici sa kojima su razgovarali Palmer, Cicos, Voker i ostali, pa i ja, naišli su na iskaze po kojima: 1. u šutki možeš da učestvuješ na način na koji želiš / ali moraš pomoći ako neko padne u ,šutki” ili skoči u publiku... 2. ne smeš zapravo udarati ljude oko sebe ${ }^{26} \ldots 3$. ne smeš na nepristojan ili seksualni način dodirivati osobe oko sebe... 4. ,šutka” se izvodi samo u prostoru predviđenom za šutiranje. Imajući saznanje o navedenim pravilima izvesno je da se zapravo ne radi o totalnom haosu, već ritualu koji, i pored haotične forme, počiva na nepisanim ali vrlo jasnim pravilima koje prenose, nadziru i sprovode učesnici po principu gupne solidarnosti i individualne odgovornosti. U tome je razlika između haosa koji vidi šire društvo i ustrojstva u kom aktivno učestvuju članovi potkultura. Ono što za jedne konstruiše i kontroliše šire društvo, za druge je sistem u čijem održavanju i konstruisanju učestvuje lokalna potkulturna grupa, u sprezi kako s drugim globalnim tako i lokalnim scenama (Ristivojević 2012). Ako se ovako posmatraju motivi učestvovanja u sceni ili njenoj manifestaciji kroz koncerte, postaje jasno da čak ni pravila nisu toliko različita koliko je različit odnos prema autoritetu koji upravlja obrascima ponašanja. Dalje, kako navode autori poput Cicosa ili Gabrijele Ričes, većina ispitanika je istakla svoju asocijalnu prirodu (Tsitsos 1999, Riches, Lashua, Spracklen 2014). Ispitanici sa kojima sam razgovarao takođe su istakli asocijalnost kao bitan deo viđenja svoje ličnosti, što me je začudilo jer pomenute osobe poznajem od ranije i smatram društvenim. Ovo bi bio paradoks jer su potkulture, poput panka, zapravo i zasnovane na različitoj ali postojećoj socijalizaciji, individualizmu ali i grupnom delovanju. Ipak, važno je bilo razumeti i šta ,asocijalnost” znači za moje ispitanike. Kroz analizu narativa ispitanika došao sam do zaključka da asocijalnost, kao motiv u iskazima, zapravo znači da ove individue nisu našle svoje mesto $u$ širem društvu i to iz dva razloga: ili nisu prihvaćeni, ili su se sami distancirali u odnosu na pravila, vrednosti i ideje šireg društva i kulture iz koje potiču. Drugim rečima, proces individualizacije i „otcepljenja” od mejnstrim kulture i afiniteta masovnog društva, sproveden je kroz prihvaćene potkulturne obrasce. Na taj način, ispitanici su kroz mogućnost prelaska iz jednog u drugi socijalni kontekst našli svoje mesto u društvu, prihvaćenost i ulogu u konstruisanju društva unutar društva za razliku od onog što nazivaju „konformizmom” ili „represijom (šireg) društva”. Drugim rečima, kroz socijalizaciju i prihvatanje obrazaca potkulture stvaraju se novi identiteti i novi pogledi na stvarnost. Mladi, kroz ove svojevrsne obrede prelaza, prave

${ }^{26}$ Ljudi se udaraju za vreme ,ک̌utke” ali su ti udarci svedeni na guranje laktovima a ne udarce pesnicama. 
distinkciju između anonimnog pripadnika nedefinisane mase i aktivnog pripadnika potkulture. Na ovaj način individua postaje deo nove, grupne hijerarhije i odnosa moći, kao i deo tela koje konstruiše pravila, za razliku od šireg društva u kome jako mali broj ljudi određuje pravila ponašanja i života velikoj većini ljudi. Dakle, negiranje dominacije i pravila centra ne znači nepostojanje pravila i odnosa moći unutar margine, već samo ukazuje na demokratizaciju (lokalne) scene koja počiva na drugačijim ili čak (naizgled) suprotnim idejama, idealima i ideologiji u odnosu na centar.

\section{„Šutka” kao prostor manifestovanja mikrogrupnih ${ }^{27}$ ideologija}

Pre nego što se upustim u razmatranje načina manifestovanja i sukobljavanja različitih ideologija unutar npr. pank scene, moram se dotaći pitanja homogenosti ili pasivnosti „scene”. Kao ilustraciju navodim promene u strukturi pank scene u Beogradu. Naime, pank scena u Beogradu bi se mogla podeliti na hard kor pank, anarho pank i Oi pank scenu. Zanimljivo, među ovim scenama je veći ideološko-etički jaz nego jaz muzičkog stila. Te mikro scene nisu pasivne i mogu se smanjivati, širiti ili preklapati, u zavisnosti od promene socijalno - političkog konteksta. Ono što periodično povezuje ili odvaja scene jeste odnos prema vrednostima, pravilima i autoritetima šireg društva, zatim korelacija društvenih vrednosti i potkulturnih vrednosti mikrogrupa, kao i odnos ideologija različitih mikro scena. O ovome je govorila Sonja Žakula, ${ }^{28}$ koja je istakla kako su se od 1990. godine do početka dvehiljaditih ove tri, praktično opozitne, scene preklapale u periodima kada je šira sistemska borba bila važnija od međusobnih ideoloških sukoba. U određenim periodima delovanje grupa bilo je upereno protiv režima Slobodana Miloševića i to je bila ideja oko koje su scene bile ujedinjene. U periodima politički podeljenih scena ideološki faktor bio je presudan za distanciranje potkulturnih grupa u Beogradu. U tom periodu realnost društvenog, kulturnog i ekonomskog poniranja, kao i ratna svakodnevica i sankcije doprineli su da se mikrogrupne ideološke razmirice zamagle zarad

27 Termin „mikrogrupa” se odnosi na činjenicu da npr. pank potkulturu čine mnogi različiti muzički, stilski i ideološki pravci. U tom smislu, pod jednostavnom odrednicom „panka” možemo označiti: anarho pankere, skinse, hard korovce, grajndere, Oi ekipu, skejtere-pankere, šarpovce ili folk/ajriš pankere, koji u načelu prihvataju ovu etiketu, ali su takođe svesni razlika između grupe kojoj pripadaju i drugih grupa (npr. anarho panker i skinhead).

28 Žakula, Sonja. 2015. The separation of scene and state: the Balkanization of the Belgrade punk scene in the wake of the wars in Yugoslavia. Keep it simple, make it fast! Crossing Borders of Underground Music Scenes, Univeristy of Porto, Portugal, 15. - 17. Jul 2015. 
udruženog antisistemskog delovanja..$^{29}$ Kada su se ratovi završili, a režim Slobodana Miloševića bio svrgnut početkom dvehiljaditih, „scene” su se vratile u svoj pređašnji opozitni međuodnos definisan ideološkim ključem. U tom smislu, scene su i danas razdvojene po ovom principu, a ono što ih načelno povezuje jeste opozicija mejnstrim kulturi i u određenoj meri asocijalni ili antisocijalni karakter grupa. Vilijam Cicos, kao zajedničku nit svih mikrogrupa, vidi pobunu protiv društvenog poretka i ideologije, a lokalnu pank scenu deli na tri dela: na politički pank, apolitični (apolitical/drunk punks) pank i strejt edž scenu (Tsitsos 1999, 401). Ovu podelu u načelu prihvatam s tim što bi u slučaju npr. beogradske scene ona glasila: politički pank (anarho pank scena, delovi Oi pank scene, $\mathrm{RAC}^{30}$ grupe), apolitični pank (delovi Oi pank scene, delovi hard core scene, delovi emo, metal/death core scene), dok je strejt edž scena u Beogradu trenutno malobrojna. U suštini, većina pank i hard kor pank grupa u Beogradu su načelno političke, ali samo neke nastoje da deluju politički u praksi.

Cicos je svoju podelu dao 1999. godine kada su, čini se, scene na Zapadu bilo više podeljene nego što je to danas situacija. Imam utisak da su poslednjih godina (decenija?) pank i metal scene, izdanja i autori potisnuti na marginu, kako u svetu, tako i kod nas, što je učinilo da se scene više prepliću nego ranije. Izvesno je da su tiraži muzićkih izdanja mnogo manji nego ranije, ali i da publike ima manje što u određenoj meri rezultuje preplitanjem scena ili većim brojem pojedinaca koji sebe vide kao nosioce raznorodnih (potkulturnih) identiteta. Na Balkanu, pa tako i u Beogradu, postoje grupe koje sjedinjuju različite potkulturne grupe poput „pankera”, „metalaca”, „skinsa”, „navijača”, pa čak i ljubitelja „turbo folk" muzike, po antisistemskom i ključu alternativnog otpora mejnstrimu. U tom smislu, na koncertima SMF-a, S.A.R.S.-a, Dubioza kolektiva, Mortal kombata, Brkova i drugih bendova, publika je zaista raznovrsna a da i pored toga retko bude incidenata. Čini se da je takvo stanje posledica toga što pomenute grupe organizuju koncerte zasnovane na ideji opozicije alternative i mejnstrima, odnosno zasnovane na ideologiji bunta, a ne konkretnih političkih ideologija ili pokreta. Pomenute muzičke grupe su ,andergruand” u odnosu na mejnstrim kulturu, ali ne pripadaju specifičnim političko-ideološkim potkulturnim svetonazorima, što rezultuje okupljanjem publike različitih muzičkih ukusa, koja deli identitet buntovnika a ne naglašava specifične ideološke ideje, makar ne na koncertima navedenih bendova.

${ }_{29}$ Stanje alternativne muzičke scene i potkulture u Beogradu, i suživot, ,alternativaca" i ostatka društva sredinom poslednje decenije prošlog veka ilustruje turobni dokumentarni film „Geto - tajni život grada” Gorana Čavajde i Ivana Markova.

${ }^{30}$ RAC - Rock Against Communism je serija političkih koncerata odražavanih u Britaniji krajem 70-ih godina 20. veka. Politički i ideološki radi se o desničarskim pank (oi!) bendovima čije pesme odnosno tekstovi pesama imaju neonacističku, rasističku ili antisemitističku pozadinu. 
Ipak, pre manje od dve decenije, kada su scene ponovo počele da se razdvajaju, bilo je sukoba koji su se događali na koncertima koje je posećivala „mešovita” publika. Primer za ovo je koncertni festival koji je održan povodom 10 godina emisije „Paket aranžman”, 2001. godine u beogradskom SKC-u. Na ovom koncertu je svirao veliki broj muzičkih grupa različitih muzičkih i ideoloških usmerenja, a takva je bila i publika. Problem je nastao kada je došlo do mešanja publika grupa Dog house i Ritam nereda, gde su s jedne strane bili hard kor pankeri (uglavnom levičarskih uverenja), a s druge strane uglavnom pripadnici skinhead pokreta suprotne ideološke pozadine. Na koncertu je atmosfera bila napeta, što je bilo evidentno i u ,šutki” gde je dolazilo do provokacija, pa i koškanja. U ovom slučaju eskalacija u nasilje bila bi posledica vizuelnih izražavanja ideoloških uverenja koja se reprodukuju kroz upotrebu specifičnog načina oblačenja, opozitnih simbola i gestova, kao i verbalnog iskazivanja političkih stavova. S druge strane, prostor ,šutke” je u ovom slučaju bilo prostor demonstriranja opozitnih ideologija. ${ }^{31}$ Navedeni primer je ilustracija konstante sukobljenih mikro grupa koja se ispoljava u periodima tranzicije, kada su šire društvo ali i potkulturne grupe podeljene po političkoj osnovi a motiv zajedničkog neprijatelja nije dovoljno čvrsto definisan da bi scene bile ujedinjene. ${ }^{32}$

U prethodno navedenom primeru ideološke pozicije su jasne i one odražavaju definišuće antinacionalističke, levičarske, odnosno, nacionalističke, desničarske pozadine grupa u konfliktu. Ali, kako prostorno pozicioniranje i telesne tehnike učestvovanja u ,šutki” odražavaju ideologije i kako to može rezultovati nasiljem? Pre svega, potrebno je razumeti kako mikro scene s različitim odnosom prema grupi ili individualnosti, pravilima i kontroli manifestuju svoje ideologije. Politički i apolitični pankeri imaju zajedničkog ideološkog neprijatelja - „mejnstrim” društvo, odnosno nametnuti autoritet i pravila kontrole. Pristup ideologiji pobune protiv mejnstrima se razlikuje kod navedenih grupa. Politički (npr. Anarho) pankeri se zalažu ne za društvo haosa ili društvo bez reda, već društvo gde je red zasnovan na odgovornosti i etici, gde svaki učesnik kulturnog dijaloga svojevoljno učestvuje u održavanju reda (Kropotkin 2010). Ideal je poredak koji je

${ }^{31} \mathrm{Na}$ Zapadu, u Americi ali i u Engleskoj, Australiji i drugim državama bilo je perioda kada su određene grupe ciljano dolazile na koncerte grupa suprotnih ideoloških uverenja. Tom prilikom je dolazilo do simboličkih ili fizičkih sukoba. Dostupno na: https://www.cvltnation.com/nazi-punks-fk-off-black-flag-bad-brainstook-back-scene-white-supremacists/?fbclid=IwAR023wPgW0JIUDWMB-Ojo_ X1OMkHYRrdQafvFnTCBqWTUMXxsqS1xL4RL5s Preuzeto 15. 5. 2018.

${ }^{32} \mathrm{~S}$ druge strane, za ,šutku” koja rezultuje nasiljem mogao sam navesti bilo koji veliki, otvoreni „rok” koncert ili nekadašnje koncerte „dvestadvojke” na Trgu republike gde je, usled velikog broja ljudi kojima nisu poznata potkulturna pravila, zatim pripadnika različitih ili opozitnih potkulturnih grupa neretko dolazilo do nasilja ili povećane grubosti. 
samoodrživ bez mešanja spoljnih faktora kontrole ili nametnutih pravila. Nasuprot tome, apolitični pankeri (drunk punks) nastoje da stvore svoj socijalni prostor nezavistan od mejnstrima, oslobođen institucija kontrole ili pravila, čak i ako to rezultuje haosom (Tsitsos 1999, 400). U oba slučaja, mejnstrim je glavni simbol spoljne kontrole protiv koje se ti pokreti bune. Treći pokret, Strejt edž, takođe ima osnovnog neprijatelja u spoljašnjoj kontroli mejnstrima, s tim što ovaj pokret nastoji da postojeću spoljnu kontrolu zameni svojom, koja bi drugima nametnula Strejt edž ideale i pravila. Strejt edž pokret ipak ne vidi pripadnike šireg društva kao neprijatelje jer oni, za razliku od drugih pank grupa koje su protiv spoljašnje kontrole, imaju potencijal da se preobrate i postanu deo Strejt edža (Tsitsos 1999, 404). Strejt edž zagovara samokontrolu nasuprot robovanju porocima. Od samih početaka ovog pokreta vegetarijanizam, veganizam, uzdržavanje od korišćenja alkohola, cigareta i droga, kao i neemotivnog seksa osnova je pokreta koji nastoji da preobrati i druge članove društva. To znači da su u Strejt edž dobrodošli i članovi šireg društva koji žele da prihvate koncept samoodricanja zarad individualnog ali i društvenog boljitka.

„You still think swastikas look cool - The real Nazis run your schools" Dead Kennedys (1981)

„Death and destruction, and don't forget the chaos” Exploited (1985)

„Don't let the world push you around -Take a stand!” Youth of today (1986)

Tri pomenute scene se razlikuju i po načinu na koji se individualni ili grupni napor koristi radi postizanja ideološkog cilja. Na primer, u slučaju anarho pankera grupni napor služi postizanju cilja kroz organizovanje raznih benefita, humanitarnih koncerata, promovisanja ideja uperenih protiv seksizma ili fašizma šireg društva ili podržavanja marginalnih grupa, npr. homoseksualaca ili pripadnika romske populacije. Anarho pankeri su u direktnoj opoziciji s neonacistički opredeljenim skinhedima, ali i delom šireg društva desničarskih pogleda. Apolitični pankeri ili, kako ih Cicos naziva „drunk punks” (pankeri pijandure), manifestuju svoju anti-društvenu ideologiju pobune kroz individualno delovanje. Iako ova grupa nema striktno definisane političke ciljeve, oni nastupaju protiv „moći društvenih institucija kroz militantni individualizam i buntovni životni stil, poput konstantnog opijanja" (Tsitsos 1999, 399). Pomenuta grupa pankera opijanjem demonstrira ideju inverzije društvenih pravila, normi i ideala konformizma. Iako ovi pankeri ističu individualnost, i za njih je jedinstvo, iako manjeg obima, bitan preduslov delovanja. Minor threat je jedan od bendova koji je početkom osamdesetih godina prošlog veka pokrenuo Strejt edž pokret s idejom da se nasilje i korišćenje opojnih supstanci, do tada popularno na koncertima, prekine, te da se prihvati S.E. ideologija kao ustrojstvo koje nije zasnovano na stvaranju i nametanju pravila koje bi drugi pratili. ${ }^{33} \mathrm{U}$ začeću ovog pokreta

33 Po rečima Iana MekKeja (Ian Mckay), frontmena pomenutog benda (i vlasnika izdavačke kuče Diskord / Dischord rekords), cilj nije bio da individua stekne kontrolu 
akcenat je bio pre na individualnom izboru nego na grupnom delovanju. $U$ tom periodu mejnstrim društvo je bilo prepoznato kao neprijatelj Strejt edža jednako kao i u slučaju političkih ili apolitičnih pankera. Ipak, s novom generacijom S.E. bendova poput Youth of today, Bold ili Gorilla Biscuits menja se i odnos prema konceptu kontrole i pravila. Vremenom je ideja samokontrole postala centralna, ali su pripadnici pokreta propagirali ne samo samokontrolu već i kontrolu drugih. Rani bendovi, poput Minor Threat, zastupali su ideju da njihova borba ima za cilj pravo individue da živi nezavisno od nametnutih pravila društva, dok je nova generacija S.E, nasuprot tome, nastojala da ovlada sredstvima kontrole (Tsitsos 1999, 405). Vremenom je haos, kao sredstvo i cilj ostalih pankera, postao logička opozicija redu i kontroli koju su zastupale S.E. grupe. To je dovelo do toga da se pripadnici S.E. ne identifikuju sa pankerima. Hard kor talas kog su S.E. grupe deo, razlikovao se od pank pokreta jer su pripadnici ove potkulture svojim agresivnim ponašanjem akcentovali svoju pobunu pre nego kroz kožne jakne, čirokane ili radničke cokule, kao pankeri u Britaniji. Primera radi, pripadnici S.E. pokreta preferiraju sportski izgled, tj. odevanje u sporske dresove i majice, delom kao odraz zdravog životnog stila i ideje kompeticije, delom zbog distanciranja od uobičajenog pank stila.

Kako se ova načela i ideologije manifestuju u prostoru i pokretu? Prostor „šutke" postoji samo ukoliko se i dok se izvodi ritual. U prostoru ,šutke”, pored drugih telesnih tehnika i oblika učestvovanja, najčešće su prisutna dva načina učestvovanja: „mošovanje” i ,slemovanje”. Iako neupućenom posmatraču obe prakse deluju podjednako opasno i haotično, situacija ,na terenu” nije takva. Čini se da su dve vrste ponašanja opozitne budući da jedno odražava red a drugo haos, tj. postojanje i izostanak pravila i kontrole. I zaista, ispitanici sa kojima sam razgovarao o slemovanju (pankeri, hard korovci i metalci) isticali su da se radi o plesu ili performansu bez pravila, ali su takođe isticali da se, i pored realne opasnosti od povrede, ne boje da učestvuju zato što znaju da su ,tu svi jedni za druge”. „Ukoliko neko padne, drugi mu priskoču u pomoć, ukoliko se učesnik povredi, on ne odustaje, već sa ponosom nosi svoje ožiljke". ${ }^{44}$ Pored iskazivanja jedinstva, ispitanici šutku kao po pravilu opisuju kao ,agresiju”, „nasilje” ili „haos”, iako je sada već jasno da je situacija obrnuta. Ovakvi odgovori više služe konstruisanju slike haotičnog i opasnog, gotovo mističnog rituala prema svetu ,autsajdera”, nego što su odraz stvarnosti. Ispitanici su, na pitanje "zašto učestvujete”, nepogrešivo odgovarali da je u pitanju „razmena energije”, i da praksa „služi kao ventil za izbacivanje negativne energije”. Pomenuti odgovori govore o svesti grupnog učestvovanja i osećaju reciprociteta u smislu da

nad drugima, već da ne dozvoli da je druge stvari ili osobe kontrolišu. Drugim rečima, cilj je bio „kontrolisati ono što te kontrolišs”. http://bandwidth.wamu.org/ian-mackayeif-you-want-to-rebel-against-society-dont-dull-the-blade/ Preuzeto 15. 5. 2018.

${ }^{34} \mathrm{https}: / /$ www.altpress.com/features/stage_diving_op_ed/ Preuzeto 15. 5. 2018. 
se u „šutki” kao i na „sceni” jednako deli dobro i zlo. Zanimljivo, citirani odgovori su simptomatični ne samo za narative mojih, već i ispitanika drugih autora (Simon 1997, Tsitsos 1999), i ukazuju na način na koji potkultura i alternativna scena stvaraju okvir kroz koji akteri razumeju sopstvenu pobunu. Dodao bih da praktično isti odgovori pripadnika scena u svetu govore u prilog učenju obrazaca ponašanja kroz globalni ili Zapadni model koji se primenjuje na lokalni kontekst. Potkultura daje pravo promene diskursa o sebi i drugima, a članovi ovih grupa menjaju svoje stavove u odnosu na njih i način na koji performiraju svoje pripadništvo. Primera radi, Cicos ističe kako su dva ispitanika korigovala način individualnog učestvovanja $u$ odnosu na nekoliko godina ranije kada su tek ušli u svet panka i kada su njihove interpretacije svog mesta u grupi i način ponašanja oslikavali narativ ideologije apolitičnih pankera - pijandura. Isti autor ističe da je ponašanje aktera, dakle, strukturisano ideologijom pobune na isti način na koji je i njihovo ponašanje u ,šutki” strukturisano „pravilima šutke” (Tsitsos 1999, 412). U tom smislu, ,šutka” je sazdana od različitih pravila čije kršenje ima za posledicu ugrožavanje grupne kohezije. Iako je ovo, jasno, gruba praksa, nasilje svakako nije cilj, već se javlja kao posledica nepoznavanja ili nepoštovanja pomenutih pravila.

Situacija je potpuno drugačija u slučaju mošovanja. Fenomen „moš pita” isključuje kružno kretanje koje akcentuje jedinstvo šutke. Mošovanje je praksa koja valorizuje individualno učestvovanje naspram grupnog. Za razliku od slemovanja, prilikom mošovanja ređi su slučajevi kada učesnici priskaču u pomoć individui koja se nađe na zemlji. To, naime, ne proizlazi iz namere učesnika da nekog povrede, ili većeg nivoa agresivnosti, već to odražava ideologiju po kojoj je moša prostor ovladavanje kontrolom gde, i pored uzajamne bliskosti, nema mesta za slabe. Ta praksa ipak retko rezultira nasiljem jer je takođe strukturisana pravilima potkulture, što stvara kontekst u kome odgovor na grubost ne sme biti nasilje dokle god se pravila poštuju. I zaista, „mošeri” ističu da, iako su agresivne osobe, ne bi nikad pokrenule tuču na ulici već da im moš služi kao način da izbace „negativnu energiju” ili ,,agresiju” iz sebe. Moš pitovi deluju agresivnije od slemovanja koje izgleda haotičnije. Razlog za različite forme učestvovanja je taj što apolitični pankeri kroz svoje učestvovanje u ovoj, naizgled, haotičnoj formaciji odražavaju ideologiju slamanja svih pravila, dok pripadnici S.E. pokreta kroz svoju pobunu nastoje da steknu kontrolu i moć. Cicos navodi da pripadnici S.E. ne izbegavaju da učestvuju u slemovanju ili pomognu palim učesnicima jer su protiv jedinstva, već zbog toga što su protiv haosa i slabosti, te je njihova pobuna - pobuna protiv odsustva kontrole (Tsitsos 1999, 412). Budući da su „strejteri" preuzeli elemente slemovanja iz potkulture s kojom se nisu identifikovali, njihov način izvođenja moša zapravo predstavlja pokušaj da se u haotičan ritual unese red (Tsitsos 1999, 411). U Beogradu je ova vrsta plesa u svojoj ekstremnijoj formi, koliko je meni poznato, počela da se praktikuje sredinom prve decenije dvehiljaditih na koncertima screamo, emo, metal i death core ben- 
dova. Prvi susret s ovom praksom na mene je ostavio utisak po kome se radi o nasilnijem ponašanju od „šutke”. U početku je dolazilo do konflikta budući da je novi ples suštinski drugačiji u odnosu na ustaljenu formu ,šutke”, ali je takav pristup učestvovanju vremenom postao prihvatljiv u specifičnom kontekstu metal kor / det kor koncerata. U ovom slučaju, nasilje je bilo posledica uvođenja novih, savremenih, zapadnih načina učestvovanja koji su po svojoj formi, ali i ideološkoj pozadini bili drugačiji od ustaljenih. Čini se da primer mošovanja u Srbiji ilustruje donekle eklektičnu prirodu, kao i heterogenost domaće scene ali i fenomen glokalizacije kao konstantu.

\section{„Šutka” kao prostor manifestovanja i preispitivanja (individualnih) identiteta}

Kao što sam na početku istakao, u ovom članku ,šutku” analiziram na tri nivoa: kolektivnom, mikrogrupnom i individualnom, sa ciljem da istaknem pluralitet ne samo načina, već i motiva učestvovanja. U poslednjem delu analize koncentrišem se na najmanju grupu učesnika, a to su marginalizovane individue. Da bi bilo jasniji princip po kom individue označavam kao marginalizovane, moram objasniti organizaciju prostora na koncertima. Najopštija podela prostora koncerta je ona na prostor izvođača i prostor namenjen publici. Ispred bine je u nekim slučajevima ograda i tu se često formira nekoliko redova sačinjenih uglavnom od mlađih učesnika. U slučaju da nema ograde, prvi red i dalje može postojati, u zavisnosti od dinamike ,šutke” koja se odvija iza ovog dela publike. Oko prostora „šutke”, obično kružnog oblika, nalazi se prsten ljudi koji ili odmaraju od učešća, pomažu učesnicima ili ih guraju nazad. Oko ovog kruga je raspoređen ostatak publike koji posmatra koncert ali i događaje u ,pitu”. U narativima ispitanika, kako onih sa kojima sam razgovarao uživo tako i onih koji su na pitanja odgovarali preko virtuelnih mreža, dobio sam odgovore karakteristične ne samo za domaću već i svetsku scenu a koji odražavaju idealistički pogled. Naime, u odgovorima je isticano da "svako ima prava i može biti deo scene", kao i da "svako može učestvovati u šutki bez obzira na rod, status, klasu, rasu, godine" itd. Ovu konstantu su ispitanici isticali često i vrlo ponosno. I zaista, mnogo svetskih muzičkih grupa pank i metal podžanrova akcentuje jedinstvo i demokratizaciju scene koja prihvata svakog. Ipak, kada sam na jednoj specijalizovanoj grupi postavio pitanje o pravu a potom i praktičnosti učestvovanja $u$ „šutki”, dobio sam odgovore koji su zapravo bliži stanju zatečenom na koncertima. Neki iskazi su odražavali stav po kome „klinci” ili devojke ne bi trebalo da učestvuju u ,šutki” jer je to ,previše opasno za njih”. ${ }^{35}$ Bilo je i onih koji su

${ }^{35}$ Ispitanici, čiji su iskazi bili dijametralno različiti od globalno prihvaćenih načela scene, svesni su toga i često su naglašavali da žele da ostanu anonimni. 
napisali da je to „muška stvar”. Javni iskazi ovog tipa su retki upravo zbog toga što postoji potkulturni okvir koji svim pripadnicima daje korpus stavova koji oni načelno dele. Ipak, jasno je da u ,šutki”, prostornoj manifestaciji „scene” gde su svi jednaki bez obzira na razlike, postoje oni koji su „malo više jednaki od drugih". Drugim rečima, očito je da i pored manifestnog distanciranja od dominantne kulture i njenih tekovina, poput patrijarhalnog pogleda na rodne odnose, pomenute vrednosti ,žive" i manifestuju se u praksi. Grupa autora na čelu sa Gabrijelom Ričis koriste teorijski okvir koji je dao Debord (Debord 1967), a koji ističe kako spektakl zamagljuje distinkciju između istine i neistine, nas i sveta (lokalnog i globalnog prim.aut.), i stvarnosti i iluzije (Riches, Lashua, Spracklen 2014, 97). Spektakli, po ovim autorima, odražavaju postojeće kulturne obrasce i služe adaptaciji osobe u određeni način života, ali i dramatizuju društvene tenzije i konflikte. Pomenuta grupa autora navodi da pesimistični stav Deborda o spektaklu kao iluziji zajednice ne mora biti u potpunosti tačan. Oni ističu ideje Kelnera i Halnona (Kellner 2003; Halnon 2004) po kojima liminalnost andergraund spektakala, poput rok koncerata ili festivala, učesnicima daju prostor u kome oni performiraju svoje identitete, ne samo grupne već i individualne, kroz koje preispituju odnose moći ili ukazuju na postojeće tenzije kako šireg društva tako i unutar potkulture.

Na osnovu prethodno navedenog, naslućujem da „scena”, koncert ili „šutka” nisu samo prostori socijalizacije i prihvatanja ideja, već i preispitivanja i otpora. U prethodnim primerima ,šutka” je služila kao arena u kojoj se dramatizuje potkulturni doživljaj socijalne represije ili kontrole, ili pak odnosi moći između mikro scena zasnovanih na oprečnim ideologijama. Takođe, jasno je da i ,scene” grade određeni oblik hijerarhije, da imaju svoj centar, ali i marginu. Ko je margina u ,šutki”? Posmatrajući najčešći način formiranja publike na koncertima, primećujem da ona ne samo da ne učestvuje na isti način, već nije ni homogena u svim aspektima paralelnog performansa. U prvom redu su najčešće najvatreniji „fanovi” grupe, ali često i mlađi i fizički slabiji deo publike. „Šutku” okružuju stariji i iskusniji članovi publike koji retko ili više ne učestvuju u njoj već taj ritual, kao i sam koncert, posmatraju sa strane. Ova grupa je relativno heterogena. „Šutka” se sastoji uglavnom od muškaraca koji pripadaju tinejdžerskoj dobi pa do ranih dvadesetih godina starosti. Stariji, kao ni najmlađi delovi publike (deca), uglavnom nisu aktivni učesnici. U razgovoru sa starijim ispitanicima dobijao sam odgovor da je to (šutka) „stvar za mlade”, ili sam nailazio na odgovore poput: ,uh, učestvovao sam ja kao klinac stalno, ali sada više ne”. Ipak, neki učesnici su istakli kako se ponekad desi da ih specifičan bend, izbor pesama ili prisustvo „starije ekipe” ohrabri, nakon čega se umešaju u ,šutku” ili čak skaču sa bine „kao nekada”. Niko na koncertu ne može zabraniti starijim učesnicima da budu deo performansa, ali je izvesno da se broj starijih učesnika smanjuje. Neki stariji učesnici ističu kako se „promenilo sve”, od scene, preko tehnologija konzumiranja i razmene muzike, socijalizacije, pa do načina učestvovanja 
u ,šutki”. To je, naravno, tačno. Ipak, ponovnim učestvovanjem u „šutkama”, stariji učesnici manifestuju svoje pravo da učestvuju, ali se čini kao da im tada ovaj ritual služi i kao poligon kulture sećanja kroz koji proživljavaju upravo periode mladosti, kada su redovno učestvovali u tim praksama nabijenim adrenalinom i testosteronom. Ta grupa ispitanika nije marginalizovana nasilno, već je vremenom prešla iz jednog prostora performansa u drugi, prihvatajući ideju po kojoj ,za sve postoji vreme i mesto”, te da je to ,ipak stvar za mlade”. Pored starijih, postoji i grupa mladih muškaraca koja ne učestvuje. Naime, već sam napomenuo da pripadnici S.E. pokreta manifestuju svoju moć i kontrolu kroz dramatizovane ali grube pokrete u „mošu”. Teatralnost mošovanja ne ostavlja utisak samo na posmatrače sa strane, koji nisu upoznati s „pravilima scene”, već i na mlade pripadnike koji tek uče kako da nađu svoje mesto. Neki od mlađih ispitanika su istakli kako ne žele da učestvuju jer se plaše povreda ili im se jednostavno ne dopada način na koji se ova praksa izvodi. Navedeni odgovor je takođe prisutan kod većine, naročito mlađih, ispitanica koje smatraju da bi bilo opasno da učestvuju.

Ipak, posebno zanimljivo mesto u ,šutki” pripada upravo ženama. Iako pripadnice „lepšeg” pola, neke od ispitanica sa kojima sam razgovarao učestvuju na način koji demonstrira da one nisu nužno i „nežniji” pol. Učestvovanje devojaka se razlikuje od učestvovanja muškog dela publike. Kao što sam pomenuo, ispitanici na socijalnim mrežama, budući da su se poistovećivali sa potkulturom, davali su idealističke ali ne i realne odgovore. Istina je da sam kroz posmatranje i razgovor došao do zaključka da u Beogradu ,šutka”, iako potkulturna specifičnost, takođe odražava deo identiteta učesnika koji ih vezuje za njihovo mesto u širem društvu. Taj deo identiteta potiče iz vaspitanja patrijarhalnog društva. To se posebno ogleda u dve vrste odgovora muških ispitanika. S jedne strane, dobio sam odgovor po kome devojke ne bi trebalo da učestvuju jer „tu nemaju šta da traže”, po kome je ,šutka muška stvar”. Takvi odgovori su retki, ne zato što nema ljudi koji tako misle, već zato što se takav stav kosi s idejama jedinstva potkulture i posebno antiseksizma, a budući da su ispitanici svesni da se od njih očekuje poznavanje i saobraženje s pravilima scene, koriguju svoje odgovore. S druge strane, dobio sam odgovore koji takođe odražavaju patrijarhalni senzibilitet ali na drugačiji način. Neki od ispitanika su istakli da za devojke nije sigurno da učestvuju jer postoji mogućnost da se povrede, te da oni kada vide da je devojka u „šutki” prilaze kako bi ,joj pomogli” i ,izvukli je nepovređenu”. Grupa autora, koju sam već pomenuo, naišla je na slične iskaze doduše unutar scene ekstremnog metala u Lidsu (Riches, Lashua, Spracklen 2014). Ti autori su istakli da devojke, učestvovanjem, preispituju predstave o ženi kao pasivnoj, slabijoj i zavisnoj od muške ili bilo čije zaštite (Riches, Lashua, Spracklen 2014, 95). Grupa autora na koncertima ekstremne muzike u Engleskoj primećuje isto što i ja na pank koncertima u Beogradu, a to je specifičnost ,šutke" kao prostora tran- 
sgresije u kome učesnice preispituju društvene diskurse o rodu i performiraju jednakost kroz sposobnost da učestvuju u ,haosu” i trpe bol ili povrede jednako kao i muškarci. Neke od ispitanica ističu kako vole da učestvuju u „šutki”, dok druge ističu učešće u ovom ritualu kao njihov način da praktično demonstriraju volju da se bore za svoju jednakost bez obzira na fizičke ili socijalne posledice. Na taj način, učesnice su koristile telesne tehnike i znanje o načinu učestvovanja kako bi demonstrirale svoje pravo da budu deo rituala koji, iako teatralan, održava odnose moći kako šireg, tako i potkulturnog društva.

Prethodno sam ukazao na to da različite mikro grupe kroz šutku performraju različita ideološka načela. Ovo važi i za učesnice koje se identifikuju s određenim potkulturnim načelima, a koje uz to performiraju i identitet žene, nastojeći da ukažu na svoju jednakost. Kao što sam pomenuo, specifičan odnos učesnika na koncertima S.E. grupa, gde je ,šutka” plato za ostvarivanje dominacije i marginalizovanje nedovoljno jakih, a gde i devojke učestvuju, tako postoje i scene poput anarho panka koje imaju opozitni odnos prema ,šutki”. Naime, ta scena je zasnovana na idejama antifašizma, antipatrijarhalnog ustrojstva, antimačo stava i antiseksizma koji se ispoljava i u ,šutki”. Na koncertima anarho bendova u Beogradu uobičajeno je, i poželjno, da pripadnici svih rodova, klasa, rasa ili starosnih grupa učestvuju zajedno jer to ne odražava samo grupnu solidarnost već i otelotvorenje ideala. Neke od ispitanica iz ove grupe demonstriraju te principe ne samo unutar svoje mikrogrupe, već i van nje budući da je ideja anarho pokreta ne samo da se udalji od ideja šireg društva već da kroz aktivizam menja svet oko sebe. Primera radi, ispitanica iz Beograda, koja pripada navedenoj grupi, ispričala je kako je zajedno s prijateljicom došla u sukob s delom publike na koncertu u Nemačkoj. Kada je koncert krenuo, a ubrzo i „šutka”, dve devojke (ispitanice) ušle su u prostor ,šutke” i počele da igraju na način na koji su navikle. Ubrzo je došlo do komešanja, i dva ili tri muška učesnika stali su ispred njih u znak protesta što one učestvuju, insistirajući da one napuste prostor. Kontrareakcija ispitanica je bila da učestvuju u ,šutki” još žustrije, što je pokrenulo još nekoliko devojaka da učine isto. Učesnice su primenile obrazac karakterističan za lokalnu varijantu globalne (anarho) pank scene, i kroz ritual manifestovale ideologiju rodne jednakosti. „Šutka” još jednom postaje proprište simboličke ali i fizičke borbe koja, u navedenom slučaju, za cilj nije imala sticanje dominacije ili kontrole, već osporavanje prava druge, dominantne strane da kontroliše. Na taj način prostor ,šutke” je demokratizovan, a devojke su, kroz telesne tehnike i neverbalnu komunikaciju, dovele u pitanje mušku dominaciju nad prostorom, demonstrirajući ideale svojih (mikro) grupa i performirajući svoj ženski identitet. Navedeni primer prikazuje čin koji, kroz teatralizovano kreatanje i akcije, ne samo da simbolički preispituje odnos ideala i prakse, već i postavlja dve pomenute učesnice u centar borbe za moć ili barem jednakost. Neke od učesnica ponekad skaču sa bine. Kroz taj deo rituala manifestuje se 
poverenje koje sam ranije pominjao. Ispitanice, ipak, prave razliku između skakanja na andergraund i mejnstrim koncertima. Distinkcija, u ovom slučaju, nije se ticala samo poverenja u publiku u smislu izražavanja bojazni od toga da li će skakač biti sigurno uhvaćen, već da li će biti napadnut. Na većim koncertima ili festivalima, gde publika nije homogena, bilo je slučajeva seksualnog uznemiravanja, tj. dodirivanja intimnih delova tela učesnica koje stoje u publici ili dok ih publika nakon skoka nosi na rukama. Zaista, veliki, svetski poznati festivali poput Lolopaluze (Lollapalooza), Bonaro (Bonnaroo) ili ACL (Ostin Siti Limits) susreću se sa problemom nekorektnog ponašanja prema ženskom delu publike, nepristojnog ili seksualnog dodirivanja u publici. Na Vudstoku 99 bilo nekoliko prijava silovanja, a Bravala festival je otkazan nakon nekoliko prijava seksualnog napastvovanja. ${ }^{36} \mathrm{~S}$ druge strane, ispitanice ističu da je ova pojava retka na lokalnim andergraund koncertima na kojima „se svi znamo”. Razlog zbog kog je ova praksa retka na andergraund koncertima je, prvo, što postoji ideja zajedništva i bliskosti a potom i poznavanja i pamćenja, a drugo, zbog toga što se na koncertima mnogo manjeg obima, kao što su lokalni, lako utvrđuje i sankcioniše kršenje obrazaca na kojim grupa počiva a vinovnici (trajno) isključuju.

\section{Završna razmatranja}

Ovaj članak je rezultat istraživanja i analize ,šutke" kao performativne ritualizovane prakse i prostora koji sagledavam kao kompleksnu arenu odnosa moći, kontrole i ideologija, u kojoj se prelamaju diskursi šireg društva, potkultura, mikrogrupa i individua. Pokazalo se da „šutka” nije haotični spektakl nasilja već kompleksni ritualni proces koji svoju strukturu duguje (Zapadnim) potkulturnim okvirima kroz koje učesnici promišljaju i preispituju sopstvene identitete, unutargrupnu i širu (lokalnu i globalnu) društvenu stvarnost. Iako je osnovni cilj istraživanja bio razumevanje same prakse, njenih pravila i strukture, a posebno odnosa grubosti i nasilja, kroz analizu sam došao i do određenih zaključaka o homogenosti potkultura, kao i o odnosu potkulture i (dominatne) kulture i društva.

Koristeći se manje ličnim, a više iskustvom ispitanika, učesnika andergraund koncerata, kao i rezultatima istraživanja drugih autora, ustanovio sam da potkultura, pa time i ,šutka" kao manifestacija iste, često nastoji da predstavlja opoziciju u odnosu na obrasce ponašanja društva ili kulture koji je okružuju. Pomenuta opozicija je važna za (kontrakulturni) identitet potkulturnih grupa i njenih članova koji se okupljaju oko ideologije bunta. Ipak, ako uporedim odnos iskaza i prakse manifestovanja raznorodnih grupnih i individualnih iden-

${ }^{36} \mathrm{https}$ //tucson.com/entertainment/music/artists-fans-want-festivals-to-address-sexualharassment/article 053c66ed-1933-54fd-8eb0-0588cb7c888f.html Preuzeto 15. 5. 2018.

Етноантрополошки проблеми, н. с. год. 13 св. 4 (2018) 
titeta učesnika, naslućujem određeni nivo diskrepancije na nivou manifestno: latentno, tj. ideala i prakse. ${ }^{37}$ To je razumljivo budući da osnovni, globalni potkulturni obrasci potiču sa Zapada, a adaptirani su u lokalnom kontekstu. S jedne strane, iskazi učesnika odražavaju identifikaciju s idealnim (idealizovanim?) zapadnim modelom potkultunog suživota i homogenosti, dok u praksi unutargrupni i međugrupni odnosi, u nekim slučajevima, odražavaju odnose i vrednosti preuzete iz dominantne kulture. Na primerima organizacije i interakcije potkulturnih grupa uviđam različite alternativne odgovore na društvenu stvarnost ali i refleksiju društvenih odnosa moći i diskursa. Išao bih toliko daleko da kažem da je kod članova potkultura često primetan ambivalentan odnos prema širem društvu i kulturi gde, s jedne strane, pojedinac manifestno iskazuje antagonistički stav, dok s druge strane reprodukuje obrasce i strukturu šireg društva u potkulturi.

Vratimo se na priču o haosu i nasilju. Kao što se vidi iz priloženog, „šutka” predstavlja teatralizaciju i performans koji je vizuelno haotičan i nasilan, ali je zapravo kompleksno strukturiran kroz skup potkulturnih pravila. Do nasilja unutar „šutke” može doći ako se određena (nepisana) pravila prekrše. Ukoliko učesnici ne dele ideje ili znanja specifična za potkulturu, već učestvuju u ovom ritualu izvan andergraund konteksta (npr. na velikom ili mejnstrim koncertu) veće su šanse da će grubost eskalirati u nasilje, ne samo jer se učesnici ne poznaju, već i zato što im nisu poznata pravila grupe koja se razlikuju od onih u spoljnjem svetu. $\mathrm{Na}$ andergraund koncertima učesnik mora da pokaže volju da istrpi bol ili nelagodu zbog šireg dobra, a ne da reaguje na način uobičajen u širem društvu. Odnos između naučene akcije i reakcije čini razliku između grubosti kao sredstva sticanja poverenja, i grubosti koja vodi nasilju. Posledica ustupka jeste uspostavljanje ili jačanje međuljudskih veza unutar grupe. Takođe, ukoliko se performiranje, karakteristično za „šutku”, izvodi izvan konteksta, bez medijuma muzike, van prostora u kom se ovaj ritual inače odvija, ili na način koji ne podržava poželjan oblik učestvovanja, ponašanje se percipira kao agresivno i to može izazvati nasilnu reakciju. ${ }^{38}$ Preduslov nenasilnog izvođenja ,šutke” je,

${ }^{37}$ Kako su pokazali u ovom radu citirani članci, a koji se bave američkom ili engleskom andergraund scenom, na Zapadu je vrlo sličan odnos između idealnog modela i njegove u nekim slučajevima potpuno opozitne realizacije.

${ }^{38}$ Dok sam radio na ovom istraživanju pokušao sam da izvedem neku vrstu eksperimenta. U jednom malom beogradskom klubu okupio se određen broj mlađih metalaca a na bini je svirao „thrash” metal bend. Povod je bio snimanje spota pomenutog benda. Više puta publika je pravila šutku ne spontano već na znak, što je bilo veštački ali su učesnici ubrzo počeli da se ponašaju kao da su na stvarnom koncertu. U jednom trenutku sam zamolio bend da zatraži od publike da pokrene šutku, ovaj put bez muzike. Učesnici su to i uradili, sa nešto manje entuzijazma ali su brzo stali. Citiram komentar jednog od učesnika koji je stajao pokraj mene, a koji je tada rekao: „ovo je baš gej”. Kada sam ga 
dakle, pretpostavljana homogenost grupe koja izvodi ritual. Ipak, kako se pokazalo, grupe najčešće nisu homogene, niti međusobno nezavisne već se do određene mere preklapaju. Iako sam načelno prihvatio podelu mikrogrupa koju je dao Cicos, napominjem da on govori o kontekstu američke scene i kulture koja služi kao idealni potkulturni model na globalnom nivou. Na lokalnom nivou, npr. u slučaju potkultura u Beogradu, primećujem da se ne radi o jednako homogenim potkulturama, ali i da je u zavisnosti od društvenog i političkog konteksta moguće preklapanje naizgled srodnih a ipak različitih „scena”. To takođe može da stvori kontekst za izbijanje nasilja na koncertima. Primera radi, „šutka” može eskalirati u nasilje ukoliko u jednom performansu učesnici opozitnih ideoloških pozadina performiraju svoj mikrogrupni identitet. Čak i ako učesnici ne odražavaju svoj politički ili ideološki identitet vizuelno ili verbalno, oni kroz „šutku” to rade neverbalno, kroz prostorno pozicioniranje i način učestvovanja. $U$ tom slučaju njihov način učestvovanja može biti prepoznat kao opozicija idejama ili represija uperena ka široj grupi učesnika (npr. pripadnik strejt edža koji, svojim učestvovanjem, želi da ostvari kontrolu unutar konteksta anarho ili koncerta apolitičnih pankera koji su protiv spoljne kontrole). U tim slučajevima može doći do nasilja budući da se ne radi o istim ideološkim pozadinama, a time ni pravilima učestvovanja. Nasilje takođe može biti indukovano i u slučaju da su odnosi moći unutar potkulture centralizovani i odražavaju hegemoniju i hijerarhizaciju karakterističnu za šire društvo, a koja ugrožava marginalnu grupu, npr. rodnu grupu. Na primeru žena-učesnica u ,šutki” ukazao sam na to da u praksi neki od učesnika manifestuju patrijarhalni princip koji, kao i drugi odnosi moći, pripada kontekstu šireg društva a ne (globalno prihvaćenoj) potkulturnoj ideji jednakosti. U ovom slučaju, nasilje ili konflikt se javlja između dve strane od kojih jedna odražava, a druga negira i preispituje dominantne obrasce i ideje šireg društva unutar potkulture.

Manifestno, negacijom ustaljenih izvora kontrole, ritualima sticanja poverenja i ideologijom bunta uspostavljaju se specifični, potkulturni (naizgled kontrakulturni) okviri vrednosti, te socijalne veze. S druge strane, iako se „šutkom”, kao prostorom socijalizacije, demonstrira zajednička ideologija buntovništva uperena protiv „represije, kontrole i pravila” šireg društva, mikrogrupe počivaju na međusobno različitim etičkim i ideološkim idejama a time i pravilima i odnosima moći. U tom smislu, ukazano je na veoma različite poglede na svet grupa

pitao šta je time želeo da kaže, učesnik je rekao da je bez muzike ,šutka” ništa više nego gužva u kojoj muškarci naskaču jedni na druge i guraju se. To je potvrdilo tezu po kojoj „ک̌utka" nije šutka ukoliko se ne izvodi u pravom kontekstu. Čak i pomenuta „ک̌utka” za potrebe spota nije predstavljala glumu. Nakon snimanja jedan od starijih učesnika prokomentarisao je to što su svi učesnici bili umorni i znojavi, a neki i lakše povređeni: „kakva gluma bre, crk`o sam, ovo je bilo za pravo, ili radiš to kako treba ili ne radiš”. 
poput političkih pankera (anarho, oi), apolitičnih grupa pankera i pripadnika strejt edž/hard kor grupa, čiji se način učestvovanja jednako razlikuje koliko i njihov odnos prema autoritetu, pravilima i kontroli. Datim primerima manifestovanja ideologija mikrogrupa, jasno je da pomenute grupe nastoje da ovladaju kontrolom, te stvore određene hijerarhije i odnose moći. To je primetno i u slučajevima potkulturnih mikro grupa koje, kao svoju specifičnost, upravo ističu negaciju pravila, hijerarhija, odnosa moći i kontrole (kao specifičnosti šireg društva). U pomenutim slučajevima izvesno je da u određenoj meri društveni odnosi, karakteristični za šire društvo, vremenom bivaju preslikani u kontekstu potkulture. Štaviše, po toj logici, interni odnosi potkultura odražavaju odnose moći spoljnjeg sveta, ali individuama i grupama daju prostor bunta i uspostavljanja odnosa moći.

Potkultura, dakle, do određene mere socijalizuje, često manifestno asocijalne individue idejom kolektivne ideologije bunta, (mikro) gupnom pripadnošću razvija identitet, socijalni i simbolički kapital (Bourdieu 1984) pojedinca, a sistemom (nepisanih) pravila pravi distinkciju između poželjnog i opasnog, tj. ponašanja koje manifestuje postojeću strukturu grupe ili je ugrožava (Daglas 2001). Zanimljivo, kao i u širem društvu, pripadnici dominantnih grupa neretko deluju kao konformisti, dok marginalizovani pojedinci, grupe i klase svojim učestvovanjem i ponašanjem preispituju potkulturne obrasce, vrednosti i strukturu, a iznad svega, njene stvarne opozicije s dominantnom kulturom. Čini se da na sva tri nivoa, kolektivnom, mikrogrupnom i individualnom, kao identitetski reper figurira opozicija mi: oni, ali je zanimljivo da $u$ zavisnosti od konteksta u kom se izvodi performans, kao i identiteta učesnika, ta opozicija ne mora nužno odražavati samo odnos šireg društva i potkulture kojoj pojedinac pripada, već može odražavati i unutargrupne tenzije. Pored toga, na osnovu analize prakse i iskaza ispitanika na sva tri nivoa, u slučaju opozicije mi: oni ulogu medijatora ima kontrola, (društvena) moć a time i hijerarhizacija, što ukazuje na određeni stepen refleksije strukture šireg društva unutar potkulture. ${ }^{39}$

„Šutka” predstavlja simboličku, transgresivnu praksu, te borbu dominacija kulturnih, grupnih i individualnih identiteta. U tom smislu, članak bih završio mišlju Džoa Ambrousa po kome je ,šutka ili metafora za život, ili nije ništa” (Ambrose 2001), međutim, na osnovu prikazanog u ovom radu, rekao bih da je šutka ili metafora za kulturu i društvo, ili nije ništa.

39 Odnos kulture i potkulture, ali i odnos potkulture, mikro grupe i individue, na osnovu iznešenog u ovom članku možemo posmatrati kao analogiju koncepta (unutar) kulturne dijalektike te fenomena otpora i pregovaranja koje Stjuart Hol koristi kada govori o hegemoniji, hijerarhiji i dominaciji kulture (Hall 1981). 


\section{Literatura}

Ambrose, Joe. 2001. Moshpit: The Violent World of Mosh Pit Culture. London: Omnibus Press.

Atran, Scott. 2002. In gods we trust: The evolutionary landscape of religion. New York: Rutgers University.

Bourdieu, Pierre. 1984. Distinction: A Social Critique of the Judgement of Taste. New York: Routledge.

Clinton, Heylin. 1993. From the Velvets to the Voidoids: A Pre-Punk History for a Post-Punk World. New York: Penguin Books.

Daglas, Meri. 2001. Čisto i opasno. Beograd: Biblioteka XX vek.

Debord, Guy. 1967. Society of the Spectacle. New York: Zone Books.

Đorđević, Jelena. 1997. Političke svetkovine i rituali. Beograd: Dosije.

Đorđević, Jelena. 2012. Studije kulture. Beograd: Službeni glasnik.

Girard, Rene. 1986. The Scapegoat. Baltimore: The Johns Hopkins University Press.

Hall, Stuart. 1981. „Notes on deconstructing the popular”. U Peoples history and socialist theory, ur. Raphael Sammuel, 442-453. New York: Routlege \& Kegan Paul.

Halnon Bettez, Karen. 2004. Inside Shock Music Carnival: Spectacle as Contested Terrain. Critical Sociology 33 (3): 743-779.

Kellner, Douglas. 2003. Media Spectacle. London: Routledge.

Kropotkin, Petar. 2010. Anarhija. Beograd: Centar za liberterske studije.

Kulenović, Nina. 2011. Socijalna ontologija u filmu „,Avatar”: antropološka analiza. Beograd: Univerzitet u Beogradu - Filozofski fakultet, Odeljenje za etnologiju i antropologiju.

Lukić Krstanović, Miroslava. 2010. Spektakli XX veka: Muzika i moć. Beograd: Srpska akademija nauka i umetnosti - Etnografski institut.

Lull, James. 1987. „Thrashing in the pit: An Ethnography of San Francisco Punk Subculture". U Natural audiences: Qualitative research of media and effects. Ur. Thomas Lindelof, 225 -252. Norwood: Ablex publishing corporation.

Merriam, Alan P. 1964. The anthropology of music. Illinois: Northwestern University Press Evanston.

Milenković, Miloš. 2010. Istorija postmoderne antropologije - Intertemporalna heterarhija. Beograd: Etnološka biblioteka.

Morton, Francis. 2005. Performing Ethnography: Irish Traditional Music Sessions and New Methodological Spaces. Social \& Cultural Geography 6 (5): 661-676.

Naumović, Slobodan. 1998. Romanticists or Double Insiders? An Essay on the Origins of Ideologised Discourses in Balkan Ethnology. Ethnologia Balkanica 2 (2): 101-120.

O'Hara, Craig. 2001. The Philosophy of Punk: More Than Noise. Chico: Ak press.

Palmer, Craig. 2005. Mummers and Moshers: Two Rituals of Trust in Changing Social Environments. Ethnology 44 (2): 147-166.

Pogrebin, Robin. 1996. „Hard-Core Threat to Health: Moshing at Rock Concert”. The New York Times 9. maj.

Riches, Gabrielle, Brett Lashua i Karl Spracklen. 2014. Female, Mosher, Transgressor: A 'Moshography' of Transgressive Practices within the Leeds Extreme Metal Scene. Journal of the international Association for the study of popular music 4 (1): 87-100. 
Ristivojević, Marija. 2012. Rokenrol kao lokalni muzički fenomen. Etnoantropološki problem 7 (1): 213-233.

Silverberg, Jesse L, Bierbaum Matthew, Sethna P. James i Cohen Itai. 2013. Collective Motion of Humans in Mosh and Circle Pits at Heavy Metal Concerts. Ithaca, New York: Cornell University.

Simon, Bradford. 1997. „Entering the Pit: Slam-Dancing and Modernity”. Journal of Popular Culture 31(1): 149-176.

Stanojević, Dragan. 2007. Od potkulture do scene i plemena: postbirmingemski pristupi u analizama odnosa omladine, muzike i stila. Sociologija. 49 (3): 265-282.

Stanojević, Dragan. 2008. Hardkor scena i masovni mediji u Srbiji. TEME 32 (3): 509-529. Tsitsos, William. 1999. Rules of Rebellion: Slamdancing, Moshing, and the American Alternative Scene. Popular Music 18 (3): 397-414.

Trbojević, Danilo. 2015. „Tales from the Belgrade pit: performance, identity, communication and violence at underground concerts". Rad predstavljen na međunarodnom naučnom skupu Univerziteta u Portu Keep it simple, make it fast! Crossing Borders of Underground Music Scenes, Portugal, Porto 15. - 17. Jula.

Trivers, Robert. 1971. The evolution of reciprocital altruism. Quaterly review of biology 46 (1): 35-57.

Turner, Victor. 1969. Limminality and communitas. Chicago: Aldline Publishing.

Turner, Victor. 1974. Dramas, Fields, and Metaphors: Symbolic Action in Human Society. New York: Cornell University Press.

Žakula, Sonja. 2015. „The separation of scene and state: the Balkanization of the Belgrade punk scene in the wake of the wars in Yugoslavia". Rad predstavljen na međunarodnom naučnom skupu Univerziteta u Portu Keep it simple, make it fast!Crossing Borders of Underground Music Scenes, Portugal, Porto 15. - 17. Jula.

Žikić, Bojan. 2012. Popularna kultura: nadkulturna komunikacija. Etnoantropološki problem 7 (2): 315-341.

\section{Korišćeni izvori}

Janjatović, Petar. 1997, Ilustrovana Enciklopedija YU Rocka 1960-1997, Geopoetika. Pogrebin, Robin. 1996. „Hard-Core Threat to Health: Moshing at Rock Concerts”. The New York Times. 9th May.

\section{Elektronski izvori}

https://kismif.eventqualia.net

http://www.imdb.com

http://matadornetwork.com

http://home.sandiego.edu

http://www.nytimes.com

http://www.facebook.com 


\section{Spisak ispitanika:}

Igor Kuzmanović, Stefan Maksimović, Vasil „Vasse” Vasev, A. Rogić, R. Radovanović, Sonja Ž, Nikola P., Kole Bogdanović, Igor „Đubre” Aleksić, „Džedaj Bašić”, L.M., N.B., I. L., M.Đ., S.S.

Danilo Trbojević

$\mathrm{PhD}$ candidate, Department of Ethnology and Anthropology, Faculty of Philosophy, University of Belgrade, Serbia

Between music and violence: „Šutka” (mosh pit) as a ritualized performance of identity and ideologies

Alternative music scene in Belgrade is created and developed almost parallel with that in the West. Members of musical subcultures have adopted norms, values and patterns of behavior based on the Western model, to a certain extent. Nevertheless, the domestic ,underground" scene is a reflection of a constant process of glocalization rather than a complete global and local uniformity. Although the „scenes" were separated to some extent in the beginning, changes in the social, cultural and political context led to the occasional permeations of various subcultural groups. The mentioned permeations also reflected on the concept of the ultimate spectacle, the performance of subcultural socialization and communication - the concert. A specific aspect of individual and collective participation in the performance of contemporary rock concerts is "šutka" (Mosh pit). The aim of the research is to point out the multi-layeredness and complexity of parallel performances that take place on stage, in the audience, and in the interspace, in a way specific to metal and punk ,,underground concerts". In the article, I am trying to investigate at what level and to what extent mentioned subcultures are countercultures indeed, ie. in what ways in concerts, through ,šutka”, they question patterns, values, power relations, hierarchies, and the hegemonies of a wider society, and to what extent they are only reflections of the dominant culture in small.

Key words: „,̌utka”, mosh pit, concert, subculture, ,underground”, violence, identity, performance 


\section{Entre la musique et la violence: «Le moshing » comme performance ritualisée des identités et des idéologies}

La scène musicale alternative à Belgrade naît et se développe presque parallèlement avec celle en Occident. Les représentants des sous-cultures musicales ont, jusqu'à un certain point, adopté les normes, les valeurs et les modèles de comportement se conformant au modèle occidental. Cependant, la scène « underground » locale représente le reflet du processus constant de glocalisation plutôt que de l'harmonisation complète du global et du local. Bien que les « scènes » aient au début été partiellement séparées, les changements du contexte social, culturel et politique amenaient à des entrecroisements sporadiques des différents groupes sous-culturels. Les entrecroisements mentionnés ont eu des effets aussi sur le concept du spectacle ultime, de la performance de socialisation et de communication sous-culturels - le concert. L'aspect spécifique de la participation individuelle et collective dans la performance des concerts de rock contemporains est «le moshing ». La recherche a pour objectif de rendre compte de la superposition et de la complexité des performances parallèles qui se déroulent sur scène, dans le public, et dans le mosh pit, et cela d'une manière caractéristique des « concerts underground » métal et punk. Dans mon article je tente d'explorer à quel niveau et à quel point les sous-cultures mentionnées sont réellement des contre-cultures, c'est-à-dire de quelle manière dans les concerts, à travers " le moshing " elles remettent en question les modèles, les valeurs, les rapports de force, les hiérarchies et même les hégémonies de la société tout entière, et jusqu'à quel point elles restent des reflets de la culture dominante en petit format.

Mots clés: « le moshing », concert, sous-culture, « underground », violence, identité, performance

Primljeno / Received: 21.05.2018.

Prihvaćeno / Accepted: 17.11.2018. 